Portland State University

PDXScholar

5-9-1997

\title{
The Controversy Over the Portland Public Schools' African-American Baseline Essays, 1983-1992
}

Thomas Damian Rand-Luby

Portland State University

Follow this and additional works at: https://pdxscholar.library.pdx.edu/open_access_etds

Part of the History Commons

Let us know how access to this document benefits you.

Recommended Citation

Rand-Luby, Thomas Damian, "The Controversy Over the Portland Public Schools' African-American Baseline Essays, 1983-1992" (1997). Dissertations and Theses. Paper 5304.

https://doi.org/10.15760/etd.7177

This Thesis is brought to you for free and open access. It has been accepted for inclusion in Dissertations and Theses by an authorized administrator of PDXScholar. Please contact us if we can make this document more accessible: pdxscholar@pdx.edu. 


\section{THESIS APPROVAL}

The abstract and thesis of Thomas Damian Rand-Luby for the Master of Arts in History were presented May 9, 1997, and accepted by the thesis committee and the department.

COMMITTEE APPROVALS:

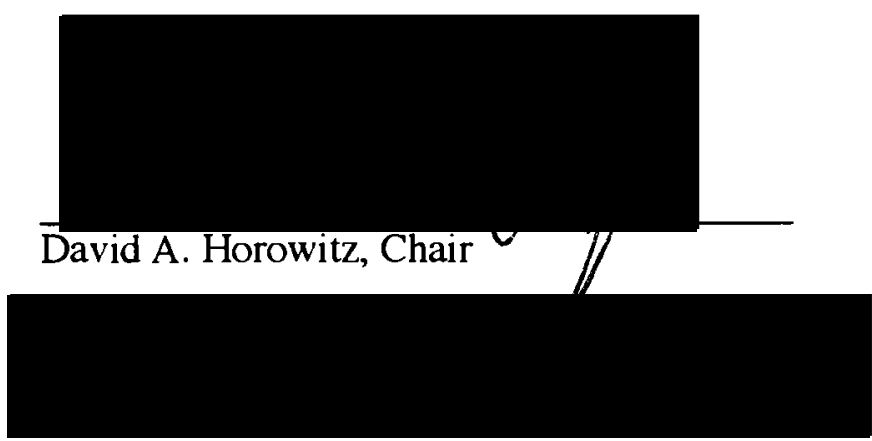

Friedrich Schuler

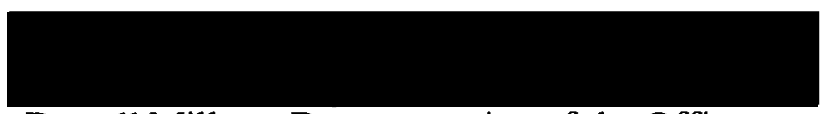

Darrell Millner, Representative of the Office of Graduate Studies

DEPARTMENT APPROVAL:

Gordon Dodds, Chair

Department of History

$* * * * * * * * * * * * * * * * * * * * * * * * * * * * * * * * * * * * * * * * * * * * * * * * * * * * * * * * * * * * * * * * * *$

\section{ACCEPTED FOR PORTLAND STATE UNIVERSITY BY THE LIBRARY}

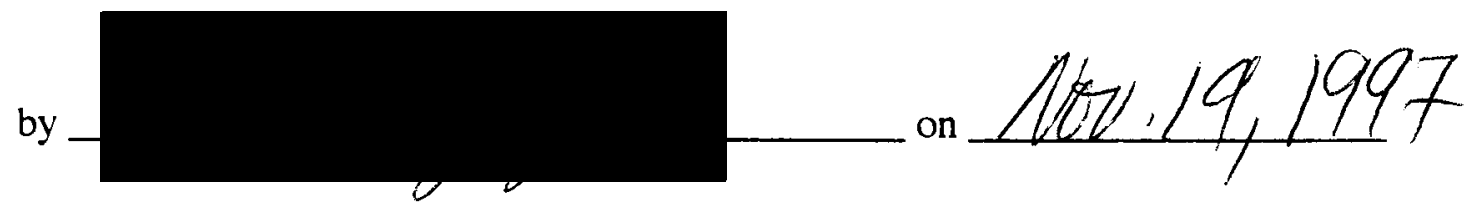




\begin{abstract}
An abstract of the thesis of Thomas Damian Rand-Luby for the Master of Arts in History presented May 9, 1997.
\end{abstract}

Title: The Controversy Over the Portland Public Schools' African-American Baseline Essays, 1983-1992.

This thesis chronicles the controversy surrounding the implementation of the multicultural education curriculum in the public schools of Portland, Oregon between 1983 and 1992. It surveys and discusses the germane events, processes, procedures, and perceptions which led up to, accompanied, and emerged from the city's adoption of the African-American Baseline Essays. This work seeks to place the Portland experiment in an historical context by revealing its contribution to the study of United States social/cultural history and race relations. This story of community empowerment is tied to long-standing conflicts and questions surrounding the nature of multicultural education, the role of public schools in America, and the larger theme of the place of race in the continual re-structuring of the American identity. 
The conflict enveloping the creation of the District's African-American Baseline Essays is analyzed through primary materials furnished by the Portland Public Schools' Archives, including articles within the Multicultural/Multiethnic Office. Besides newspaper items, national periodicals, and monographs, conversations between the author and anonymous individuals intimately involved with the controversy proved invaluable.

As public education has historically been a forum upon which unresolved conflicts have played themselves out, the controversy over multicultural education in the Portland Public Schools made a vital and potentially useful contribution. The District's African-American Baseline Essays and the heated response which followed had a significant impact on multicultural education and the larger issues of ethnic and race relations and American identity. While Americans have witnessed painstaking efforts to expand the understanding of the varied tapestry of their culture over the past twenty-five years, the controversy over the Portland Public Schools' AfricanAmerican Baseline Essays played a role in the nation's historic struggle to seek a coherent identity among an increasingly diverse community. 
THE CONTROVERSY OVER THE PORTLAND PUBLIC SCHOOLS'

AFRICAN-AMERICAN BASELINE ESSAYS, 1983-1992

by

THOMASDAMIANRAND-LUBY

A thesis submitted in partial fulfillment of the requirements of the degree of

\section{MASTER OF ARTS}

in

HISTORY

Portland State University

1997 
DEDICATION

For

My Family 


\section{ACKNOWLEDGMENTS}

I am very grateful that this thesis project was completed under the guidance of Dr. David A. Horowitz, whose influence is found in every paragraph. I am also thankful to Dr. Darrell Millner, whose input was indispensable. Moreover, the numerous and anonymous exchanges with individuals intimately involved with this conflict proved invaluable. In addition, I deeply appreciate the kindness, patience, and assistance of Carolyn Leonard, Chris Blackburn and David Evans of Portland Public Schools, and Tina Tinkersly of the Portland State University History Department, along with the many librarians at Portland State. 


\section{TABLE OF CONTENTS}

ACKNOWLEDGMENTS iii

INTRODUCTION. 1

CHAPTER

I THE ROOTS OF THE MULTICULTURAL DEB ATE.

II PORTLAND AND THEMULTICULTURAL CURRICULUM CONTROVERSY .26

III THE CREATION OF THE PORTLAND PUBLIC SCHOOLS' ESSAYS.

IV THE RESPONSE TO PORTLAND'S AFRICAN-AMERICAN BASELINE ESSAYS.

V CONCLUSION. 90

ABBREVIATIONS .95

NOTES 97

REFERENCES 105

APPENDIX A 126

APPENDIX B 130 


\section{INTRODUCTION}

In the fall of 1988 , the predominantly white public school system of Portland, Oregon became the first in the nation to fully commit to a multicultural curriculum. Portland based its reforms on the African-American Baseline Essays, a series of resource documents that served as modeis for programs in predominantly black districts within Atlanta, Indianapolis, Prince George's County, Md., and Washington, D.C. The Portland district began by adding an African-American emphasis in third, fourth, and fifth grades. Eventually, the curriculum was to be expanded to all grades and include the contributions of Hispanic, American Indian, and Pacific Island cultures. Asa Hilliard, Portland's chief consultant, proclaimed that the documents promised to offer the district a "solid national recognition," and observed that at least five national black organizations had endorsed the classroom innovation. $^{1}$

Questions of race, ethnicity, and religion have been a perennial source of conflict in American education. Providing a forum on which social conflict played itself out, the schools have of ten attracted the zealous attention of those who wish to influence the future, as well as those who wish to change the way the past is viewed. American schools have served as institutions in which youngsters were taught skills and knowledge, but also as an arena in which interest groups have fought to preserve their values, revise the judgments of history, or to bring about fundamental social change. Nineteenth century Protestants and Catholics, for example, battled over which version of the Bible should be used in public schools, or whether the Bible should be used at all. For most of its history, however, American public school education attempted to neutralize controversies over race, religion, and ethnicity by ignoring them. Up to the 1960 s, schools emphasized white male- and 
elite-centered political and institutional history from an Anglocentric perspective which presumed that all citizens would eventually lose or abandon their ethnic characteristics. $^{2}$

With its long history of ethnic, racial, and cultural diversity, the United States historically sought to reduce social tensions and conflict by attempting to construct an overarching national culture. This cluster of ideas, institutions, and habits was described by Swedish sociologist Gunnar Myrdal as "the American Creed." The ideals of the essential dignity and equality of all human beings, of inalienable rights to freedom, justice, and opportunity, contended Myrdal, were reflected in all of America's institutions, including its schools. ${ }^{3}$

By the the 1960s and early 1970s, however, the American Creed appeaared to be under severe attack in school districts in which there was a high percentage of black and Hispanic students. Paralleling the political and social changes of the 1960 s and 1970s, educators increasingly recognized cultural pluralism as an organizing principle of society. Social conflicts over ethnicity, race, and identity began to penetrate long-standing debates over public school curricula. Starting in the early 1970 s, widely used textbooks were carefully screened to eliminate bias against minority groups and women and were designed to emphasize the full historical experience of such groups. ${ }^{4}$

Leading the way was the state of California. In 1987, the California school system adopted a new curriculum framework which called for students to be taught about world and United States history in considerable detail. New York State adopted a reform curriculum during this same period. In both cases, educators conf ronted vocal representatives of ethnically and racially defined groups seeking "better" treatment of their respective contributions to American society. Among the 
most forceful of such lobbyists were self-styled "Afrocentrists." Primarily comprised of black scholar-activists and educators, Afrocentrists sought to place Africa at the center of the curricula and insisted that ancient Egypt, which they defined as "black," was the cradle of western civilization. Afrocentrists such as Leonard Jeffries, chair of Black Studies at the City University of New York, divided Americans into two antagonistic groups: European-Americans and non-Europeans. ${ }^{5}$

James A. Banks, professor of education at the University of Washington and a nationally recognized expert on multicultural education, argued in 1990 that “[s]chools must teach about and foster respect for the various groups that make up American society." Advocates of multiculturalism education like Asa Hilliard, an educational psychologist at Georgia State University, argued that teaching children about contributions from their racial or ethnic group would increase self-esteem and, in turn, achievement. Some multiculturalists drew a connection with a fundamental of good teaching: build on what children already know, namely their culture. Others like Diane Ravitch, professor of history and education at Teachers College, Columbia University, advocated a pluralist approach, which promoted a broad interpretation of "the common American culture" and the contribution of its many ethnic, and racial groups. $^{6}$

This thesis chronicles the controversy which surrounded the implementation of the multicultural education curriculum in the public schools of Portland, Oregon between 1983 and 1992. Using primary materials furnished by the District, along with local and national periodicals, and essays, it surveys and discusses the germane events, processes, procedures, and perceptions which led up to, accompanied, and emerged from the city's adoption of the African-American Baseline Essays. This work seeks to place the Portland experiment in an historical context by revealing its 
contribution to the study of United States social/cultural history and race relations. This story of community empowerment will be tied to long-standing conflicts and questions surrounding the nature of multicultural education, the role of public schools in America, and the larger theme of the place of race in the continual restructuring of the American identity. 


\section{CHAPTER ONE}

\section{THE ROOTS OFTHE MULTICULTURAL CURRICULUM DEBATE}

Ethnic, racial, and cultural diversity in the United States originated in a threecentury migration of a mixture of people to the American continent. Seventeenth century English settlers confronted some 200,000 indigenous people in the eastern woodlands. At the time of the American Revolution, the English constituted threefifths the new nation's population. Yet non-English Europeans made up a significant part of the colonial population. By 1776 there were 250,000 Scots-Irish in the United States. Germans, who numbered over 200,000 , were the second most significant European minority. About 15,000 Huguenots, Protestant refugees from Roman Catholic France, and smaller numbers of Scots, Dutch, and Swedes rounded out the American population. Meanwhile, thriving tobacco, indigo, and cotton plantations in the southern states produced an African-American slave labor force that enveloped one-fourth of the new nation's population. ${ }^{1}$

As population growth and industrialization produced unstable social conditions in nineteenth century Europe, steamship and railroad technology facilitated the migration of millions of the continent's peasants. The United States received over 37 million of these immigrants between 1820 and 1930. Up to 1880, most emigrants came from Ireland, Germany, and the United Kingdom. By the turn of the twentieth century nearly four million Irish, five million Germans, and four million British subjects (including English) had arrived in the United States. Another onethird million Chinese and Japanese Americans lived in the country by 1900 . By then, the African-American population of former slaves had grown to nearly nine million. ${ }^{2}$ 
Although immigrants came mainly from northern and western Europe before 1880 , southern, central, and eastern Europeans dominated the enormous migration that followed. Between 1880 and 1920, eleven million newcomers arrived from Italy, Russia, Poland, the Balkans, the Baltic states, and the Austro-Hungarian empire. Some 2.3 million of these arrivals were Jewish. Most of the rest were of Roman Catholic or Orthodox faiths. A fourth wave of immigration accompanied the end of World War II in 1945, and included political refugees from Cuba and Communist nations in East Asia and eastern Europe as well as migrants from the Caribbean, Latin America, and the western Pacific. ${ }^{3}$

American ethnic and racial diversity was celebrated by cultural pluralists as a source of national vitality. Perhaps the nation's first such theorist was Hector St. John de Crevecoeur, a French emigre to British New York. Writing in Letters from an American Farmer, a series of essays published in 1782, Crevecoeur marveled at the astonishing diversity of the surrounding settlers, a hodge-podge of "English, Scotch, Irish, French, Dutch, Germans, and Swedes," a "strange mixture of blood" not to be found in any other country. The French observer described the intermarriage of different nationalities with great fervor. "From this promiscuous breed," he mused, "that race now called Americans have arisen." Crevecoeur defined a new cultural ideal. " He is an American," he wrote,

who leaving behind him all his ancient prejudices and manners, receives new ones from the new mode of life he has embraced, the new government he obeys, and the new rank he holds. He becomes an American by being received in the broad lap of our great Alma Mater. Here individuals of all 
nations are melted into a new race of men ... The American is a new man, who acts upon new principles. ${ }^{4}$

George Washington, the new president of the United States, repeated Crevecoeurs's melting-pot metaphor. "The bosom of America," observed Washington, was " open ... to the oppressed and persecuted of all Nations and Religions." Washington instructed upstarts to prepare for "intermixture with our people[,]" so they would be "assimilated to our customs, measures and laws; in a word, soon become one people." 5

Similar celebrations marked the work of some of the nineteenth century's most distinguished writers and visitors. "You can not spill a drop of American blood without spilling the blood of the whole world[,]" declared Herman Melville. "On this Western hemisphere all tribes and people are forming into one federated whole[.]" For Ralph Waldo Emerson America was the "distillation of the multifarious globe." Emerson described America as an "asylum of all nations," where "the energy of Irish, Germans, Swedes, Poles, and Cossacks," as well as that of the "Africans, \& of the Polynesians, will construct a new race... as vigorous as the new Europe which came out of the smelting pot of the Dark Ages."

Alexis de Tocqueville, a young Frenchman who arrived in the United States seventy-five years after Crevecoeur, repeated his predecessor's metaphors. Tocqueville encountered "a society formed of all the nations of the world," people having "different languages, beliefs, opinions: in a word, a society without roots, without memories, without prejudices, without routines, without common ideas, without a national character." Commitment to democracy, self-government and civic 
participation, Tocqueville argued in Democracy in America in 1835, was the great educator and the great unifier. ${ }^{7}$

When James Bryce, the next great foreign commentator on American Society, wrote. The American Commonwealth in 1888 , immigration had vastly increased and diversified. What struck Bryce was what had amused Tocqueville: "the amazing solvent power which American institutions, habits, and ideas exercise upon newcomers of all races[,]...quickly dissolving and assimilating the foreign bodies that are poured into her mass." Similar themes, among these the prospect of interfaith marriages between Jews and Gentiles, were addressed in The Melting Pot, a popular play of 1908 written by Israel Zangwill, an English writer of Russian Jewish origin. As late as 1944 another foreign visitor had described a cross-cultural "American Creed." Americans "of all national origins, regions, creeds, and colors," wrote the Swedish social scientist Gunnar Myrdal, held in common "the most explicitly expressed system of general ideals" of any country in the West: the ideals of the essential dignity and equality of all human beings, of inalienable rights to freedom, justice, and opportunity. ${ }^{8}$

Despite the "melting pot" allegory of Crevecocur and others, the continuous waves of European and Asian immigrants and the presence of a large AfricanAmerican population fit awkwardly into a society that was predominately English in language, ideals, institutions, and culture. A deeply bred racism placed people of color- red, black, yellow, and brown Americans, as well as many European ethnicswell outside the pale. During colonial times English settlers of tentimes distrusted newcomers of other ethnic origins, disdained their "uncouth presence," and feared their perceived economic competition, alien religions, and folkways. "The common fear," one eighteenth century Pennsylvania official noted at the time, "is that if they 
[the Scotch-Irish] thus continue to come they will make themselves proprietors of the Province." Germans and Scandinavians were regarded as clannish in their fidelity to the language and customs of the old country. German beer gardens and "jolly Sundays," moreover, excited puritanical disapproval. Nineteenth century IrishCatholics, in turn, were regarded as shiftless and drunken papists, whose fealty of Rome supposedly prevented them from becoming loyal Americans. ${ }^{9}$

The fastest growing political force in the Northeast during the 1850 s was the secret anti-Catholic and anti-foreign Know-Nothing movement. Represented by the American Party, this coalition promised to return power to ordinary citizens by providing a direct primary to choose party nominees by majority vote in local lodges or councils. Fearing the alleged power of Rome and the Catholic church over American politics and society, hundreds of thousands of men joined nativist lodges. The Know-Nothing movement died in the 1850 s, but in 1887 a new anti-Catholic group, the American Protective Association (APA) was formed in Clinton, Iowa, by Henry Bowers, a fifty year-old German Lutheran, who had failed as a farmer and enjoyed modest success as a self-taught lawyer. Appealing to working-class Protestants, the APA dedicated itself to preserving public schools and eliminating Catholic "political control." The APA soon won the support of more than 2.5 million Protestant Americans, mainly in the Midwest and Rocky Mountain states. It reached the zenith of its power during the depression of the 1890s and then appeared to lose influence. Yet another nativist organization, the Immigration Restriction League, rose to take its place. Founded in Boston in 1894 by wealthy patricians, the League called for the use of literacy tests to discourage immigration from "inferior" Slav, Latin, and Asiatic races. These measures, supported by the Republican party, passed Congress in 1896, only to be vetoed by President Grover Cleveland. After 
another veto by Woodrow Wilson, Congress passed the Immigration Act of 1917, which imposed a literacy test. ${ }^{10}$

Racial nativism also influenced the response to immigrant diversity. After Congress passed the Chinese Exclusion Act of 1882, President Theodore Roosevelt negotiated an informal prohibition of Japanese immigration in the Gentleman's Agreement of 1907. The state of California even passed a 1913 law that prevented Japanese and other foreigners from owning land in their own name. Meanwhile, from the 1890s forward, African-Americans found themselves victimized by a series of southern state governments which institutionalized racial segregation of public facilities, disenf ranchised black male voters, and encouraged ritualistic lynchings and acts of terror against assertive black men. In Plessy $\mathbf{v} \cdot$ Ferguson (1896), the Supreme court of the United Stated upheld the doctrine of "separate but equal" as it applied to state public school education. ${ }^{11}$

Themes of racism and nativism came together in the 1910s in the Jeffersonian, a newspaper published by Georgia populist Tom Watson. Watson's diatribes against Catholics, Jews, and African-Americans facilitated the rebirth in 1915 of the Ku Klux Klan, a secret terrorist group that had targeted former slaves and Union soldiers in the post-Civil War South. The new Klan officially rejected violence and built a massive political machine of some five million members in the 1920 s by focusing on alleged Catholic and foreign threats to American moral purity. ${ }^{12}$

Klan racial and cultural attitudes reflected much of early twentieth century intellectual thought and scholarship. Imbued with New England restrictionist thought, intellectuals like Harvard-trained historian Lothrop Stoddard interpreted the Bolshevik Revolution of 1917 as a rebellion of depressed races against Nordic 
dominance. After World War I, social scientists produced statistics suggesting that 46 percent of America's foreign-born soldiers had low intelligence. National Prohibition, enacted in 1919 , symbolized, in part, the contempt by nativists for drinking and the saloon culture of the immigrant masses. During the 1920s, Henry Ford, the billionaire pioneer of automobile mass production, led an anti-Semitic campaign against "international Jews," whose loyalties were allegedly not to America but to "greedy interests." The brouhaha surrounding the 1928 presidential candidacy of Democrat AI Smith, an urban, Irish-Catholic, demonstrated the perceived threat to Anglo-Protestants and their notions of purity, and order. The crowning legacy of post-war nativism was the Johnson-Reed Immigration Act of 1924, which instituted a rigid quota system designed to limit immigration and discourage migrants from southern, central, and eastern Europe. ${ }^{13}$

As the appeal of Henry Ford's polemics demonstrated, anti-Semitism thrived in the 1920s. Harvard president A. Lawrence Lowell, a national vice-president of the Immigration Restriction League who lamented the growing numbers of ethnics among the student body, called in 1922 for quotas on Jewish admission to colleges so that the predominance of Ango-Saxons could be preserved. During the 1930 s xenophobic groups like William Pelley's Silver Shirts joined some advocates of nonintervention in Europe in protesting alleged Jewish influence in American life. Yet Nazi Germany's status as an enemy of the United States in World War II delegitimized such expression. Nevertheless, racial animosity contributed to political pressure to incarcerate West Coast Japanese-Americans in internment camps during the war. $^{14}$

Race relations in the United States were significantly influenced by the 1.6 million migration of African-Americans from the South to the cities of the Middle 
West, Far West, and the Northeast that accompanied the high tide of segregation, disfranchisement, and racial violence between 1910 and 1930. Reacting to the accomodationist strategy of black American leader Booker T. Washington, a group of white and black Progressives, including African-American scholar W.E.B. Du Bois, formed the National Association for the Advancement of Colored People (NAACP) in 1909 in order to press for civil rights and political freedoms. To open up opposition in the labor market, the Urban League was established in 1911 as the major social-welfare agency working among blacks. Settlement of African-American communities in the North facilitated the "Harlem Renaissance," a black literary and artistic movement of the 1920s. Cultural revitalization embodied the aspirations of the "New Negro," who was militant and proud of his/her race, and desired to perpetuate group identity, while participating fully in American society. AfricanAmerican intellectuals and artists now demanded rights of citizenship, while seeking to enrich the larger culture with the traditions and history of their people. In 1936, the National Negro Congress (NNC) emerged among black labor leaders and New Deal reformers who criticized the NAACP and the Urban League for failing to engage the economically depressed black masses and working class. ${ }^{15}$

As American industry retooled for war production in 1940 and 1941, NNC leader A. Philip Randolph threatened a massive march on Washington unless President Franklin D. Roosevelt desegregated the defense industry. In response, Roosevelt issued Executive Order 8802, which established the Fair Employment Practices Committee. Although the order was poorly implemented, millions of African-Americans participated in defense work and served in the armed forces during World War II. Meanwhile, economic diversification, military spending, and labor shortages helped spread urban prosperity across the South. ${ }^{16}$ 
These patterns, including economic growth and the continuous litigation of the NAACP, helped set the stage for a postwar civil rights movement whose first major victory was Brown v. Topeka, the landmark 1954 Supreme Court decision that mandated the racial desegregation of public schools. Inspired by the triumph, civil rights leaders like Reverend Martin Luther King, Jr. and other grassroots activists built a movement culminating in the Civil Rights Act of 1964, which outlawed racial discrimination in public accommodations and employment, and the Voting Rights Act of 1965 , which permitted the use of federal registrars to insure access to the ballot for racial minorities. As African-Americans surpassed 11 percent of the American population by the mid-1960s, blacks looked forward to both integration into the mainstream of national life and celebration of the strengths of their culture. $^{17}$

Despite the achievements of the Civil Rights movement, its failure to spread benefits beyond the African-American middle class led to a resurgence of black nationalism in the late 1960s. African-American protest had long been characterized by the polarities between integration and black nationalism. Early integrationists included David Walker, whose Appeal ... to the Colored Citizens of the World (1829) described America as a land which "we have watered with our tears and our blood [and] is now our mother country[.]" In the 1850s, Frederick Douglass, a former slave and tireless integrationist, denounced the notion that "Africa, not America" was the home of black Americans and suggested that "[n]o one idea has given rise to more oppression ... toward the colored people of this country[.]" Contrary to these integrationist professions, a marginal, yet passionate, nationalist tradition surfaced. One proponent of such an orientation was Martin R. Delany, an early advocate of pan-Africanism and a back-to-Africa campaign. Born of a free 
mother and a slave father in Virginia in 1812, Delany witnessed the degradation of slavery in the South and white racism against blacks in the North. Both prompted him to be a spokesman for the rights of African-Americans. As he grew older, however, Delany embraced emigrationism. Delany attempted to persuade American black leaders to pursue a course of self-determination in which they would see themselves as a distinct group of people whose cultural heritage was African, not European. It was imperative, according to Delany's estimation, for black Americans to work for racial solidarity between themselves, West Indians, and Africans. Furthermore, African-Americans also had to realize that the abolition of slavery was merely the beginning of Africa's regeneration. Nation-building on the African continent, he continued, was its logical conclusion. ${ }^{18}$

Although Delany's efforts bore little fruit, the idea of African-American repatriation was taken up again by Marcus Garvey. Born in 1887 in Jamaica, the West Indies, Garvey became the twentieth century's first key black nationalist. In 1914, he founded the Universal Negro Improvement Association (UNIA), which he moved to the United States in 1917. The UNIA became the first mass movement for working-class blacks in the northern ghettos. While the NAACP and the Urban League continued to struggle for black justice and approval in the white community, Garvey attracted a much larger following by speaking to the despair, frustrations, and relative powerlessness of urban blacks. The movement enrolled about 100,000 members at the peak of its appeal, although Garvey claimed as many as two million. The most popular and charismatic black leader of the 1920s, Garvey's second wave of black nationalism preached racial pride and inspired poorer followers to dream of freedom and economic self-sufficiency under black leadership. Through pageantry 
and passionate proclamations, the Jamaican leader sought to elevate the self-esteem and sense of solidarity of African-Americans. ${ }^{19}$

Describing himself as the provisional president of the African Republic, Garvey demanded an "Africa for the Africans." While established leaders such as W.E.B. Du Bois and his middle-class associates of the NAACP disdained anything African, Garvey suggested that a limited number of American blacks might go to Liberia to teach the skills necessary to redeem Africa from European colonialism. Garvey maintained that an African nation had to be established where blacks would "be given the opportunity to develop by themselves, without creating the hatred and animosity that now exist[s] in countries of the white race." By 1922, however, UNIA businesses faltered through mismanagement and federal prosecutors indicted Garvey for selling fraudulent stock to support the organization's Black Star Steamship Line, which had proposed to establish a commercial link between the United States, the West Indies, and Africa. After Garvey served two years in federal prison, the federal government deported him in 1927 as an alien who had committed a felony. ${ }^{20}$

Although the UNIA collapsed, the zeal of black nationalism never left the ghetto. In the 1930s a split in the Moorish Science Temple led to the creation of the Nation of Islam under the leadership of Messenger Elijah Muhamad. In the third wave of American black nationalism, Muhamad developed a theology which described Islam as the true religion of black people, portrayed blacks as chosen people, and marginalized the white man as a devil. Consequently, social and political separation from whites was a divine imperative, necessary in order to avoid the "corruptive influence of white civilization." To accomplish this, Muhammad called 
for "a united front of black men of America" to join a program of economic, political, and spiritual upliftment of black people. ${ }^{21}$

A fourth wave of black nationalism surfaced in the mid-1960s when the nonviolent and integrationist approach of Martin Luther King, Jr. and the southern civil rights movement confronted challenges by black power advocates. Frustrated by the persistence of American racism and repression, and race riots in slums like Watts, Detroit, Washington, and Newark, militant activists in the Student National Coordinating Committee (SNCC) led the movement away from racial integration to black power, moved to purge whites from leadership positions, and sought to disassociate itself from a rhetoric of non-violence. During 1966, SNCC Chairman Stokely Carmichael inaugurated the slogan of "Black Power," a term designed to instill feelings of pride and cultural identity among African-Americans. In Black Power: The Politics of Liberation in America (1967), Carmichael and political science professor Charles V. Hamilton asserted that blacks must re-define themselves without white help. Black power represented a nationalist and revolutionary ideology which rejected white American culture and paralleled the nationalist movements of formerly colonized peoples in Africa and the Third World. Proponents such as Carmichael shared the views of earlier black separatists by concluding that black Americans needed to strengthen their own community. "Integration was a subterfuge for the maintenance of white supremacy[,]" and facilitated the idea that "white" was superior to "black," insisted Carmichael. ${ }^{22}$

Black Power also drew on the legacy of the Black Muslim leader, Malcolm $\mathrm{X}$. Born Malcolm Little, he had converted to the Muslim religion while in prison in the 1950s and changed his name to Malcolm X in order to symbolize independence from white domination. Recognizing the importance of achieving political power as 
a pre-condition for racial progress, Malcolm rejected the limited horizons of racial integration and, instead, called for self-defense against police brutality and other instances of racism. "A revolutionary," he declared, "is a black nationalist." An influential and charismatic speaker, Malcolm initially opposed inter-racial political cooperation, arguing that any association with "evil whites" would prevent the attainment of social justice. But after he broke with the Black Muslims in 1964, Malcolm became convinced that capitalism functioned as an oppressive force in the world and that people of all colors must cooperate to achieve a socialist al ternative. Assassinated in Harlem in 1965, Malcolm had an enormous effect upon black and white radicals through his posthumously published The Autobiography of Malcolm $\underline{X}(1964) .{ }^{23}$

Malcolm X's insistence on the self-defense of black communities greatly interested the Black Panther Party, founded in Oakland, California in 1966 by Huey Newton and Bobby Seale. Attracting media coverage out of proportion to its actual membership, the Panthers asserted their right to carry guns for self-defense and to monitor police actions as a way of inhibiting the unnecessary use of force. The Panther weekly newspaper blasted police brutality, racism, and white domination of the justice system. Each week it printed the group's 10-point program, which expressed opposition to the evil of "welfare colonialism" and demanded trial by a jury of one's peers, decent housing, full employment, and control by black people over their own communities. The Panthers also established local health clinics, and provided free breakfasts and schools for African-American children. Nevertheless, Panther rhetoric and hostility to law enforcement opened the movement to reprisals from local police and FBI forces. ${ }^{24}$ 
Black nationalist and black power ideologies found expression in the works of numerous African-American intellectuals in the late-1960s and 1970s. "To be black and conscious in America," explained novelist James Baldwin, "is to be in a constant state of rage." Eldridge Cleaver, a former convict and emerging leader of the Black Panther Party, expressed similar fury in his best-selling Soul on Ice (1968). "You are either part of the solution or part of the problem," Cleaver later declared. New black nationalist organizations proliferated across northern cities in the second half of the 1960s. They included SNCC, the Committee On Racial Equality (CORE), the Republic of New Africa, the US Organization of Ron (Maulana) Karenga, and the Black Community Development and Defense Organization of Imamu Baraka. Like previous expressions of black nationalism, these groups reflected the economic and social despair of urban blacks and skepticism about the promises and rewards of racial and cultural integration. ${ }^{25}$

Amid and as a response to these perceptions, Stokely Carmichael enunciated in 1968 a growing realization that black Americans had a common bond not only among themselves, but with their "African brothers," and had a history which predated their coerced introduction to the United States. Anti-colonial struggles abroad were increasingly seen by black nationalists as linked to those of African-Americans, as the United States' pursuit of the Vietnam war in Southeast Asia was perceived to be further proof of its imperialistic pursuits. The revolutionary literature of third world peoples found a responsive audience among black nationalists. Maulana Karenga's US movement grew out of the efforts of Karenga, a doctoral student at the University of California, Los Angeles. Established in 1965, this body maintained a policy of teaching African-American cultural values and the psychological liberation of blacks as a "requirement before discussions of political or economic liberation." 
Karenga's movement included the writers Imamu Baraka and Haki Madhubuti, both of whom established institutions based on the Kawaida philosophy espousing familihood, unity, self-determination, collective work and responsibility, cooperative economics, creativity, and faith. Baraka, a playwright, countered "melting pot" theories and instead insisted on the vitality of a distinctive African-American culture that survived the ordeal of slavery and white racism. In Black Man's Burden (1965), John O. Killens described his trip to ten African countries: "Everywhere I went people called me brother." Alex Haley's compelling Roots (1976), a personal study of black genealogy, popularized the notion for a mass audience. ${ }^{26}$

For many American blacks the creation of nation-states in Africa in the 1960 s was proof of racial virility, as the establishment of Israel was for many American Jews. The ensuing glorification of the African past was accompanied by a campaign to replace Anglo "slave" names with African names, to wear African costumes, to replicate African rituals. LeRoi Jones, who had said in 1962 that "history for the Negro, before America, must remain an emotional abstraction," saw Africa in 1966 more concretely and changed his name to Amiri Baraka. Arthur Smith became Molefi Kete Asante and would call on others to embrace African names: "Only such a name reflects our consciousness." The black nationalists sought not only a transformation of culture but transformations of self, as the "black is beautif ul" theme flowed naturally from pride in heritage. ${ }^{27}$

An embodiment of the fourth nationalist wave was the re-naming of blacks from "Negro" to "black" to "Afro-Americans." The term "Afro-American" had indeed been used intermittently in the United States since the 1850 s and reflected black Americans' attempt to liberate themselves from frustration and powerlessness. In the late-1960s, Carmichael and Hamilton cited a growing resentment of the term 
"Negro," to which derogatory connotations of accomodationism were ascribed.

They observed that vast segments within black communities, in a general effort to assert their own definitions, sought the replacement of this "oppressive term," an "invention of our oppressor," with terms like "Afro-American," or "black," which connoted determination, intelligence, beauty, energy, and peacefulness. ${ }^{28}$

Another significant and enduring manifestation of the fourth wave of black nationalism was the evolution of Black Studies programs within American universities, which began in 1966 at San Francisco State College. By the mid1960s, racial rioting in the cities and the rise of black power had stimulated a more racially self-conscious and assertive activism among African-American college students. Accordingly, in 1966, the Negro Students Association changed its name to the Black Student Union (BSU). The new Black Studies discipline combined a long intellectual-activist tradition with the social visions and struggles of 1960s' black power and liberation and encompassed history, religion, social organization, politics, economics, creative production ( Arts), and psychology. ${ }^{29}$

By the late-1970s, Afrocentrism had emerged as a major conceptual framework of many Black Studies programs. The movement found its most definitive treatment in a work by Molefi Asante entitled Afrocentricity: The Theory of Social Change (1980). A professor and chair of the department of African American Studies at Temple University, Asante underscored the need of every black person to embrace an Afrocentric philosophy. Such an outlook combined the elements of philosophy, science, history, and mythology to "give us the clearest perspective on that ... particular group of people called the African-American." Regarded as the "Father of Afrocentric Research," Asante asserted that Afrocentrism was necessary to enable African-Americans to place themselves in the center of their 
self-analyses. To do this, they were to establish a historical and cultural contact linked inexorably to Africa. Without Afrocentrism, insisted Asante, AfricanAmericans could not credibly add their voice to the multicultural milieu. Moreover, teaching black children about contributions from their racial group would enhance self-worth, the largest perceived obstacle to educational fulfillment among young African-Americans. ${ }^{30}$

Asante contended that there was a single "African Cultural System," manifested wherever people of African descent were to be found. "We [people of African descent] respond to the same rhythms of the universe, the same cosmological sensibilities," he suggested, while invoking Maulana Karenga's assertion: "Our Africanity is our ultimate reality." Repudiating the notion that Africans and AfricanAmericans had nothing in common but the color of their skin, Asante alleged that "an emotional, cultural, psychological connection" existed "between this people that spans the oceans." Moreover, civilization originated in highlands of East Africa, he maintained, and our "[a]ncestors do, in fact, gather to inspire us and do bring us victory." Embodying a view of social and human reality from an "African" perspective, Asante's scholarship advanced the notion that Europeans and their white descendants no longer occupied the central and exalted position in human civilization. He portrayed Afrocentrism as encompassing "the whole panorama of human history" in order to re-construct for black Americans the cultural heritage of a homeland that other ethnic groups had "as their birthright."31

Joining Asante in endorsing Afrocentric education was Asa G. Hilliard III, an educational psychologist. Hilliard described Africa as "the mother of Western civilization" because he linked Egypt to black culture and the origins of science and philosophy. John Henrik Clarke, professor emeritus of African World History at 
Hunter College at the City University of New York (CUNY), advanced a more extreme version of Afrocentrism. Clarke, whose training was in educational psychology, alleged that multicultural education was the product of the "Jewish educational Mafia," and that "African scholars" were "the final authority on Africa," a proposition of tentimes invoked by other Afrocentric scholars. Moreover, Clarke suggested that much of the reluctance to accept Afrocentrism stemmed "from whites wanting to dominate the world and control image." Moreover, he insisted that they were unwilling "to admit that the foundations of what [is called] Western civilization were laid by non-Europeans. ${ }^{132}$

Perhaps the most militant and controversial Afrocentrist to rise to the public stage in the 1980s was Leonard Jeffries, professor and chair of Black Studies at CUNY. Professor Jeffries' anti-white, anti-Semitic diatribes were well-documented. A trained political scientist, Jeffries espoused a "Sun People, Ice People" theory, which described Europeans as cold, individualistic, materialistic, and aggressive "ice people" who emerged from caves to bring the world "domination, destruction and death." Conversely, Africans, who grew up in sunlight with the intellectual and physical superiority provided by the pigment melanin, were warm, humanistic, and communitarian "sun people." In 1987, Jeffries advised a task force that New York State's multicultural curriculum reform was "Eurocentric" and dominated by white social history. ${ }^{33}$

"An army of angry black scholars," wrote columnist Carol Innerst of the Washington Post, in November 1990, "is determined to re-claim what it says is a glorious African past that was stolen or trashed by racist white historians." Their numbers were growing, observed Innerst, as they set about re-writing school study plans and the history of mankind itself to put Africa at the center. A four-day 
meeting of the Afrocentric movement in the fall of 1990 drew one thousand black academics, twice the number who showed up at the first conference a year earlier. The history taught in schools was made up by white academics, asserted Jeffries. Its defenders, he challenged, were fighting to save something "built on a straw foundation." "Black history," claimed Asa Hilliard, was "human history. Blacks who say Afrocentrism is anti-white , argued one conference participant, "aspire to be overseers in the "white-controlled educational plantation." Outspoken critics were derided from the podium. Diane Ravitch, for example, had been referred to as a "sophisticated Jew," as Arthur Schlesinger, Jr. was dismissed as “old." Moreover, Shelby Steele, author and professor of English at California State University, San Jose, "tried to shed his race.",34

The emerging controversy over the multicultural curriculum in the nation's public schools was substantially influenced by the spread of interest in ethnic and cultural identity to other groups besides African- Americans. Young NativeAmerican radicals used the cultural crisis of the late-1960s to re-claim Indian autonomy. While Native-Americans remained poorer than blacks, the Indian population doubled from 500,000 in 1945 to one million in 1975 . In midwestem and western cities, Indians established cultural centers to revive historic traditions. Protesting against government collusion with corrupt tribal leaders, activists associated with the American Indian Movement (AIM) seized the road to Wounded Knee, South Dakota in 1973. Like the black power confrontations of the late-1960s, the exchange of gunfire between FBI officers and activists symbolized an end to psychological dependence on whites. Native-American students pushed for and received greater access to Indian Studies programs in America's universities, as the 
larger Native-American population focused increasingly on economic issues during the next two decades. ${ }^{35}$

Concurrently, Mexican-American youths in the late-1960s and early-70s embraced a "Chicano" pride by organizing the Brown Berets and carrying guns to demonstrate independence from Anglo authorities and police. Notwithstanding the bleak economic existence of many Mexican-Americans, Chicano students at southwestern universities used confrontation tactics to institute Chicano Studies programs. By the 1970s, the cultural awakening had produced scholarly journals such as Aztlan, the popular magazines El Grito and La Raza, and moving explorations of Chicano roots by novelists Raymond Barrio, Fudolfo Anaya, and Arturo Islas and film director Luis Valdez. ${ }^{36}$

Another vital affirmation of ethnicity occurred during the late-1960s among white ethnics such as Polish-Americans, Italian-Americans, Lithuanian-Americans, and many others. These groups feared that the 1960 s civil rights and anti-poverty reforms threatened to undermine their own hard-won gains. The War on Poverty, the apparent success of confrontation politics, and the growing opposition to the war in Vietnam, all created the impression to these groups that hard work, obedience to the law, and patriotism were no longer highly valued. Feeling betrayed and cheated, white ethnics in the urban Northeast and Middle West gravitated toward the "traditional values" of order, discipline, and authority. While strains of racism were a significant factor, defense of neighborhood institutions and safe communities against change imposed by outsiders played a major role in rampant opposition to "forced busing," and to public school integration. Busing represented an infringement upon personal choice and destruction of neighborhood schools by judicial authorities, civil rights activists, and "limousine liberals," who saw the 
inter-racial conflict in purely moral terms. In contrast, white ethnics, many of whom lived in the centers of large cities, believed they had been asked to bear a disproportionate expense for social experimentation. Moreover, Ethnic Studies programs emerged on campuses to distinguish and celebrate various minority groups, some of whom did not want to be "assimilated," as they began to look for "roots" that had not been homogenized. ${ }^{37}$

With roots in the civil rights and identity movements of the 1960s and early1970s, the multicultural education movement was powered in part by a desire for curricular equity. Schooling that dealt overwhelmingly with the contributions of Europeans and their white U.S. descendants, some multiculturalists pointed out, was wrong for everyone, and damaging to minorities. By the late-1980s, one-third of the nation's schoolchildren were people of color. Although the need for a more inclusive and diverse curriculum was mainly undisputed among educators, the manner in which multicultural education would be implemented would remain an issue laced with passionate controversy. ${ }^{38}$ 


\section{CHAPTER 2}

\section{PORTLAND AND THE MULTICULTURAL}

\section{CURRICULUM CONTROVERSY}

Portland, Oregon's experiment with multicultural school curicula had extended roots in the city's racial history. In 1871, four years after the Portland School Board had decided to construct a school for black children only, the panel reversed itself by opening all school doors to African-Americans and other minority children. By 1878 , the number of minority students listed in the District's annual report totaled eighteen, approximately 1 percent of Portland's total enrollment. No further action addressed the issue of minority children in the District until 1947, when the Board initiated an English as a Second Language program at one of its high schools. ${ }^{1}$

In contrast to many northern and western cities, the growth of the AfricanAmerican population in Portland had been slow. Yet race relations in Portland were significantly influenced when large numbers of blacks were drawn to the city by job opportunities in the area's World War II shipyards. Because of restrictive and overtly racist covenants and real estate practices, African-Americans tended to settle in common neighborhoods. By 1940, Portland had nearly two thousand black residents, 57 percent of whom were concentrated in what would become known as the "Albina area" in the city's North and Northeast sectors. This number grew to over 9500 by 1950 and more than fifteen thousand by 1960 , when it constituted over 4 percent of the city's population. By that year, 78 percent of Portland's black residents lived in Albina. ${ }^{2}$

Black residential concentration following World War II resulted in a dramatic increase of minority students at Boise, Eliot, King, Holladay, Irvington, and 
Humboldt elementary schools and Jefferson High School. African-Americans provided between 30 percent and 94 percent of the enrollment in these schools by 1960. Three years earlier, the Portland City Club noted in a landmark study that there was a concentration of blacks in some schools "as a consequence of residence, not by design." As the impact of residential concentration became clear, individual and group voices began to demand that Portland's school district take remedial action to bring about the racial integration mandated by the Brown v. Topeka decision of 1954. Concurrently, Harry Ward, president of the Portland branch of the NAACP, protested against the construction of Eliot School by predicting that the facility would become racially isolated as soon as it opened. Indeed, black student enrollment at Eliot soon exceeded 90 percent. $^{3}$

Portland's black community reacted to the threat of de-facto school segregation in 1962 when the local chapter of the NAACP called on the Board of Education to recognize that racial isolation created "a sense of inferiority among Black students." No solutions were offered. However, that same year the national NAACP conducted a study of the Portland school situation which recommended that districts combine the educational functions of adjoining black and white neighborhoods and build new facilities between them. As a result of community input, the Portland Board of Education responded in 1963 by creating a program designed to alleviate racial isolation and "improve the social, cultural and educational conditions of the schools in the Albina community." [see Appendix A]

In the spring of 1963, Portland's Committee on Racial Imbalance (CRI), a self-starting community group, began to address anxiety over racial imbalance within the District. An association of 100 citizens widely representative of the overall community, CRI inaugurated the modern era of desegregation/integration efforts in 
the city's public schools. Reverend Paul Wright, minister of the First Presbyterian Church who would lead the committee and serve as its chair, noted that black enrollment had reached 99 percent at Eliot, 90 percent at Boise, 85 percent at Humboldt, 85 percent at Highland, and 85 percent at Holladay. Wright told the Board of Education that the committee shared "a common concern over racial imbalance in some of our public elementary schools." Chair Wright urged that these figures clearly indicated the problem of de-facto school segregation and predicted that "the disease would spread." 5

Disturbed by the figures cited by Rev. Wright and pointing to long-stated District goals of inclusion and pluralism, the CRI asked the Board of Education to establish a study commission to embark upon a year-long investigation of racial imbalance within Portland's public schools. The Board appointed a 43-member Committee on Race and Education in July 1963. Endorsed by Superintendent Dr. Melvin W. Barnes, the panel was instructed to study whether the District deprived the children of one race of educational opportunities, what might be done to improve the educational achievement of students in the city's "culturally deprived areas," and how racial prejudice in the schools might be eliminated. Composed of local business, education, labor, and law professionals, the Schwab Committee, named after chair Judge Herbert M. Schwab, divided into six substantive working groups. After fifteen months of study, the panel presented a 250-page report to the Board of Education in October $1964 .^{6}$

Committee findings clustered around two main themes: compensatory education and the concentration of minority children. The panel concluded that Portland schools were not providing children of all races with equal educational opportunities. First, it called for the Board to deal with the input of social 
environment on the development of children and their ability to learn. Since the quality of learning was deficient in schools with "disadvantaged students," it argued, education must be upgraded for such students. "Disadvantaged children" encompassed both white and black children, with the latter possessing a higher percentage of disadvantagedness. Such pupils were believed less capable of working out of their "depressed environment." Second, the report asked the school system to create contact among children of all races in order to alleviate racial isolation and overcome the residential concentration of black students. It sought such goals within the framework of the neighborhood school concept. Specific committee recommendations included a Model School Program in facilities serving lowachievement pupils, more emphasis on the material and cultural needs of "disadvantaged children," re-evaluation of high school curricula, and more intensive counseling and guidance to remove racial prejudice. The report further called for new school construction and boundaries to reduce or avoid environmental or racial isolation. $^{7}$

Although the CRI expressed concern that the report's recommendations were too modest, the Schwab study facilitated a comprehensive attack on racial imbalance in a major school system. The chief consequence of the inquiry was the establishment in Portland of a model compensatory education program that served a number of racially unbalanced schools. Funded by state, federal and District resources, it provided for smaller class sizes, increased numbers of teacher aides, better instructional materials and student evaluation, and more individualized instruction and tutoring. To facilitate administration of the program, of ficials formed and staffed a special administrative sub-district called the Model Schools. ${ }^{8}$ 
Portland's compensatory program was coupled with a voluntary student transfer program in which African-American students could elect to be transported to predominantly white schools, which had space to accommodate them. The voluntary Administrative Transfer Program (ATP) was to be accompanied by counseling efforts to acquaint black parents with its opportunities. Four hundred and twenty-five students participated in the transfer program in 1967. In the next twelve years enrollment multiplied almost eight-fold. Meanwhile, ATP students were bused to several suburban school districts. In the 1968-1969 school year, when districtwide black enrollment was just over 8 percent of the total, almost 43 percent of such students attended "racially isolated" schools, those containing over 50 percent minority enrollment. After the Board significantly expanded its program in 1972-73 and the District's black enrollment jumped to over 14 percent, the number of AfricanAmerican students in racially isolated schools diminished to under 17 percent. This was achieved despite the significant increase in numbers of minority students and the dramatic loss in majority students, a pattern derived from demographics, the growth of the suburbs, home schooling, and "white flight" to neighboring communities and private schools. A random sample of opinion taken by an independent professional firm indicated that a majority of parents of students in the program felt that their child was receiving a superior social and educational experience. ${ }^{9}$

The arrival of Superintendent of Schools Robert W. Blanchard in 1969 coincided with and influenced the advent of the second stage of Portland Public Schools' educational reform. Known as Portland Schools for the Seventies, the plan evolved from a series of questions posed by the Board to Superintendent Blanchard, who moved to the city from a similar position in Montclair, New Jersey. Adopted in March 1970, the plan called for substantial recruitment of African- 
American parents and students for "voluntary busing" to reduce minority concentrations, conversion of model elementary schools to Early Childhood Education Centers (ECEC) to draw white students, location of middle schools for grades six to eight to capitalize on impact from feeder institutions (upper grade schools to which these lower grades advanced), and creation of district-wide magnet programs to accelerate the desegregation process. A recurrent theme within the entire plan was the improvement of instruction and efforts to encourage staff innovation in programs and processes. Through the implementation of this plan, the District provided remedies beyond the ATP to include the creation of sub-districts, magnet schools, middle schools, ECEC, and "open enrollment" as instruments of desegregation and integration. During the late-1970s officials organized more than eighty special workshops and resource meetings devoted to such topics and involved parents at both ATP "sending" and "receiving" schools. ${ }^{10}$

Despite Portland Public School's desegregation/integration efforts, representatives from the African-American community continued to challenge the District's policies. When the Board feared that racial isolation might result from the increasing enrollment of minority students at North Portland's Jefferson High School in 1977, it sought new strategies for desegregation. Among these was the Newman Plan. Drawn up by School Board member Jonathan Newman, the proposal aimed at complying with state desegregation guidelines to avert "racial isolation." It sought to accomplish this by prohibiting students in two predominantly black neighborhoods from attending nearby Jefferson High School. Instead, it proposed to bus the students to two predominantly white, west side schools, Lincoln and Wilson. Members of the African-American community expressed outrage at the Board's proposal, complaining that there had been no attempt to consult them. 
Their response challenged the "equality-at-all-costs" nature of the desegregation effort. Sensitive to the complaints from the local community, the Board deferred action on the Plan in July 1977 and asked the NAACP, the Urban League, and the city's Metropolitan Human Relations Commission to develop alternative recommendations. These organizations extended invitations to groups and individuals, thus forming the Community Coalition for School Integration (the Coalition), and ushering in a new age in race relations in Portland. Made up of seventy individuals and twenty-nine organizations, the Coalition sought to identify common concerns in the Portland community regarding school desegregation and develop appropriate recommendations. ${ }^{11}$

After an eighteen-month inquiry into school racial policy, the Coalition released an anticipated report to the Board in November 1978. The document introduced new terms into the schooling lexicon such as "equity," "burden," and "pairing, " and sought to re-formulate the neighborhood school concept. Influenced by Coalition chair Harry Ward and community activist Herb Cawthorne, the 1978 report contained the assertion that the Portland School District had not carried out school desegregation in an equitable manner. It criticized the fact that in order to create the ECEC, only schools in the black community had been targeted for the mandatory elimination of fifth and sixth grade classes, requiring these students to be bused outside of their neighborhoods. The report noted that grade levels that had been removed from "white" elementary schools were duplicated in neighboring facilities. Moreover, the Coalition Report asserted that white students in the ECEC had the option of returning to their neighborhood school, while black students did not have such choice. ${ }^{12}$ 
To support its contention, the Coaition Report cited a form used between 1973 and 1977 that required parents of ATP students to agree that, "my child will continue in the school to which he is transferred until all grades in that school are completed and that he will automatically be transferred to the feeder serving that school ." No such procedure, the document observed, was required for parents of children transferring into the black community. The result, argued the report, was that students leaving the African-American community for the purpose of school desegregation had been separated and "scattered" throughout the District. While the Coalition emphasized the uneven nature of the attempt to achieve racial integration in the school system, they underscored that integration enriched the educational experience of "all children." Moreover, the condition of racial segregation, the report continued, violated traditional American notions of opportunity and principles of sound education, left children damaged by a distorted self-image, encouraged prejudice, and prepared students poorly for the multiracial world they would enter. ${ }^{13}$

Charging that the District's desegregation/integration programs had been carried out in a fragmented manner, the Coalition urged that the program needed to be re-organized under one unit, directly beneath the Superintendent. This new unit, the document insisted, should be empowered to communicate more openly with District citizens, implement Coalition recommendations, and report annually on the progress made toward equalizing educational opportunity. Moreover, the report called for a long-term plan to encourage the recruitment of minority staff and training in multicultural perspectives and "Black" culture. ${ }^{14}$

To improve the racial balance of Portland neighborhoods, the Report called for assistance to achieve the long-range goal of housing integration through tax incentives and loan opportunities for home purchases. However, the centerpiece of 
the Report was the recommendation for "Pairing," which the Coalition believed to be the major means to achieve desegregation/integration. Citing research that school desegregation was most successful when "it starts at the early grade levels," the Coalition argued that quality programs established within the ECEC would be preserved and expanded to other levels through "pairing." This concept required both black and white students to alternate, each having several years in a school in their own, and another, neighborhood. Moreover, the Coalition insisted upon equitable elimination of grades within both communities. "School pairing is equitable," urged the Coalition document, arguing that the practice could bring about stability within the student and neighborhood populations and a more efficient allocation of resources. Finally, the Coalition Report demanded a long-range commitment to modify the curricul um to reflect the cultural diversity of Portland's population. ${ }^{15}$ Arguing that African-American students constituted the largest minority group in the District, the Coalition suggested that school officials include the teaching of "Minority cultures" with a special emphasis on "Black culture." It proposed that such topics be placed as a "Major category" in the Social Studies and Language Arts subjects for K-12 in Scope and Sequence, the basic curriculum guide for Portland's schools. The Coalition Report called for an independent survey of Portland elementary classrooms by "specialists" to determine the extent to which minority culture had been included in the social studies and language arts curricula and an assessment of how well multiethnic themes had been incorporated into classroom work in all subjects. ${ }^{16}$

School Superintendent Blanchard endorsed the aims of the Coalition Plan in December 1978, noting that his disagreement was " not one of ends or goals, but almost entirely of means." Although Blanchard confided that some of his friends in 
the Coalition had suggested that it would be "unproductive" to examine critically the details of the Report, he rejected the implication that the School District had not acted responsibly and effectively in regard to desegregation. After reciting a long list of District accomplishments, Blanchard accepted some of the Coalition's recommendations. They included a commitment to make desegregation-related teacher training mandatory, to increase recruitment of minority professionals in daily contact with students, and to hire a desegregation/integration program coordinator to aid the Assistant Superintendent in centralized coordination and monitoring of programs. He further agreed to an annual staff report to the School Board on progress toward equal educational opportunity and racial integration. Blanchard also accepted full responsibility for the implementation of Coalition recommendations adopted by the Board, an assurance sought by the group. ${ }^{17}$

Insof ar as the "pairing" proposal was concerned, Blanchard asserted that the recommendations relating to equity with the "compulsory two-way busing" proposal seemed "to raise fundamental issues that the Coalition did not address." Conceding that equity with respect to desegregation programs did not exist in pure form, the superintendent insisted that inconveniences had been almost equally shared by black and white students. The Coalition's proposal on "pairing," maintained Blanchard, would reverse a series of decisions that were approved by the Board and neighborhood communities served by these programs. He professed his long-held belief that desegregation be accomplished through educational innovations, and that transfers be voluntary. Blanchard revealed his concern that an unqualified assault on de-facto school segregation risked not only failure, but loss of progress already made. Citing serious logistical difficulties, the Superintendent assured that "pairing" would accelerate the enrollment decline, which city schools had already experienced. 
Moreover, Blanchard dismissed allegations concerning the "unwritten policy," by which only white students were to have the option to return to their neighborhood schools. ${ }^{18}$

Noting that multi-ethnic education was already being integrated into relevant curriculum, Blanchard agreed, in principle, with the Coalition's recommendation to incorporate African-American and other minority cultures into the District's required courses. Commenting on the suggestion that an independent survey be made of the District's elementary classrooms to determine the extent of minority culture material in the curriculum, he insisted that he did not believe "we need this done by an outside organization." Blanchard disclosed that he was prepared to direct his own curriculum department to conduct such a survey during the 1979-80 school year. Furthermore, he concurred with the Coalition's request for the District to acquire teaching materials oriented toward minority culture. The Portland Public Schools, he concluded, were committed to providing instruction in multiethnic education in order to help all students "develop an understanding of, and an appreciation for, the history, contributions, and cultures of Alacks, Asians, Spanish-Americans, and Native-Americans." 19

Although Blanchard implemented his curricula commitments with Board directives following January 1979, the Black United Front (BUF and the Front), a militant community action group, challenged the integrationist assumptions underlying District desegregation efforts and began to lead public demonstrations, using empowerment rhetoric and confrontation tactics. The Portland chapter of the National Black United Front grew out of conversations among a small group of African-Americans in Northeast Portland in the late-1970s. The Front embodied black nationalist strains and an Afrocentric orientation. Its meetings drew from 
twenty to 200 regulars, but it possessed the ability to mobilize thousands of Portland's African-Americans along with supportive whites. The BUF sought to generate employment opportunities, conf ronted police brutality, and pitted itself against "racist" practices within Portland Public Schools. To achieve its ends, the Front used tactics ranging from traditional negotiating techniques to noisy demonstrations. ${ }^{20}$

Ron Herndon, the Front's fiery co-chair, believed in working with African-American people at the grass roots level and targeting education as a first priority, since schooling had "always been very highly prized in the black community." Herndon claimed that "Desegregation simply means that you get rid of a system that limits... equality of education." "Busing" and "boundary movements," he insisted, were not part of such an agenda. There was no evidence, exhorted Herndon, that black children gained academically or socially through school desegregation. Yet he believed there was ample proof that busing to white schools caused emotional distress, de-stabilized local communities, and hurt self-esteem. Consequently, the Front preferred educational efforts that emphasized AfricanAmerican cultural cohesion instead of the District's desegregation efforts. Among its goals were re-invigorated efforts to strengthen general academic programs, train teacher and staff in multiethnic education and Black History, increase hiring and placement of minority teachers, and place greater curricular emphasis on black and minority cultures. Unless the Board devised a comprehensive desegregation plan along the terms supported by the Front, the BUF threatened to lead a boycott of Portland Public Schools for September 1979. ${ }^{21}$

Just before the scheduled boycott, the School Board adopted a series of resolutions that modified its Desegregation/Integration program. In the short-run, 
the Board provided for emergency provisions. They included giving parents of resident students in the Albina area the option to remain in or return to their neighborhood school, reform of the ATP program, fair discipline practices for black students, and the creation of a monitoring group made up of interested community members, with invitations extended to representatives of BUF. As a long-term objective, the Board now resolved to develop a comprehensive desegregation plan within a year. Planning was to involve a wide cross-section of the community. Parents and community were to play a role in the selection of staff for schools involved in the program. A new District director of personnel would work to increase hiring of qualified minority teachers and other staff. Teachers and administrators would be exposed to a more extensive course of instruction in the history and cultures of African-Americans, ethnic minorities, and the working class. Finally, programs and curricula directed at enhancing the self-worth and cultural identity of "Black students" were to be reviewed by staff, parents, and "various organizations," including the Black United Front. ${ }^{22}$

Responding to attacks by African -American community activists, Portland's School Board held hearings in early 1980 in which the BUF presented demands for "educational oriented remedies, not racial balance" in seven black neighborhood schools. In April, the Board adopted a Comprehensive Desegregation Plan (CDP), embraced by both the black and white communities, although Board members Frank McNamara and Forrest Rieke expressed the fear that it would lead the District back to the era of segregated classrooms and could court a federal lawsuit. Derived after nearly three years of protest, the Desegregation Plan guaranteed every child the right to attend neighborhood schools. To implement such a goal, it called for the establishment of a new middle school in the Albina District. The Board's program 
also sought to increase the number of minority applicants for jobs in the District. It further attempted to influence curriculum by mandating that students learn the skills and knowledge required for competence and excellence in a multiracial world. Finally, the Desegregation Plan announced the District's intention to create programs to train staff in the ability to enhance the self-esteem and cultural identity of minority students (namely black pupils), improve inter-racial understanding, and broaden the curriculum. ${ }^{23}$

In June of 1980 the Portland School Board's 4-3 vote to fire Superintendent Robert W. Blanchard set off what the Oregonian newspaper called the "most heated political controversy in the history of the 53,000 -student school system."

Underlying the conflict were fundamental issues about how the state's largest school district would be governed. Opponents of the ejection saw it as the culmination of a year of misguided activity by a new and inexperienced school board. Supporters claimed it represented a long-overdue transfer of educational decision-making power to "the people," and ushered in a new era of responsiveness to citizen concerns. Blanchard's ouster launched two separate recall campaigns against all board members, both of which failed. Apart from their individual objections to Blanchard, all four board members criticized the superintendent for "retreating" rather than rising to meet challenges to his positions, particularly on desegregation. Three of these four board members, which included Herb Cawthorne, the Board's only black and former leader of the Coalition, had been elected the previous year. ${ }^{24}$

Three months after the ouster of Blanchard, Assistant Superintendent of Staff Development and Community Relations Ernest E. Hartzog indicated the District's need for "intensive consultative assistance in ... multicultural education." Consultants, both local and national, who possessed "distinguished" reputations, 
would play a vital role in assisting staff to implement such goals, urged Hartzog.

These advisors, he proclaimed, would be involved in activities from the conceptual and planning stage through actual implementation and evaluation. Specifically, they would recommend particular changes and/or "advance fresh ideas" regarding discipline, multicultural education, staff training, and the curriculum. The latter was to include recommendations on materials from citizen and community groups to support education that was considered multicultural. A major goal, the assistant superintendent asserted, would be "to identify one or two individuals who will serve as primary or chief consultant throughout our period of need." Hartzog affirmed the need to make the most effective use of their time, "in the most economical manner." He identified Dr. Asa Hilliard, of Georgia State University, as a distinguished professor of education with a "proven track record" in multicultural education and in the training of "Black" children, and an expert willing to work with the District as a consultant. The assistant superintendent also uttered assurances that continual deliberation with community organizations would be maintained. ${ }^{25}$

Hilliard first visited Portland in October 1980 and was treated by District personnel associated with the desegregation/integration effort as "a knowledgeable educator who understands our situation." Soon after he agreed to serve as the primary consultant for the implementation of the CDP. Hilliard met with the Desegregation Implementation Coordinating Committee, as well as relevant departments and administrators. After reviewing the Board's plan, he saw no need to recommend changes and perceived his responsibility as one of aiding the District to "develop more specificity for the plan and to assist in the development and implementation of appropriate activities." Based upon that visit and his study of the District's materials, he prepared a written report. ${ }^{26}$ 
This initial review examined Scope and Sequence documents that had been revised in November 1980 by local staff, independent local advisors and national consultants. The assessment indicated that the first set of Scope and Sequence revisions were a significant improvement, but needed to involve national consultants identified by Hilliard. These experts, asserted the Georgia State educator, would provide the District with the "cutting edge" in order to take the curriculum revisions to a new level of sophistication. In order to receive community feedback, the revised materials were distributed by District officials to key community organizations, including the Black United Front. ${ }^{27}$

Hilliard met with the Desegregation Monitoring and Advisory Committee (DMAC) in March 1981 to familiarize the panel with some of the procedures which he had recommended to the District. DMAC had been established by the Board of Education and met for the first time in June 1980, three months before Hilliard's arrival. Including representation from the larger Portland community, it was to report to the Board at least twice each year about the "effects of the Desegregation Plan." On the basis of such reports, the Board was to re-consider strategy if satisfactory progress was not being made. Assistant Superintendent Hartzog was required to provide staff and other assistance to DMAC as needed. Carolyn Leonard, Evaluation Specialist, was to provide liaison from the District's Evaluation Department to the committee. The panel met on a regular basis. During its first year (1980-1981), however, only one report was filed with the Board. The second year, the committee divided into two sub-committees, one to look at staff hiring and the other at curriculum. However, there was not agreement by the Board as to what was expected of the committee, nor was there consensus within the group as to its role. Consequently, the panel was left to "review and report," with the assistance of 
the primary desegregation consultant, Professor Hilliard, what it felt to be important. $^{28}$ 


\section{CHAPTER THREE}

\section{THE CREATION OF THE PORTLAND PUBLIC SCHOOLS'}

\section{BASELINE ESSAYS}

Responding to Asa Hilliard's recommendations which began in early 1981, the Portland Public School District began to recruit additional nationally recognized authorities on the contributions of African-Americans and other minorities to participate in curriculum development. Hilliard requested that all curricular revision for ethnic content, including the Scope and Sequence documents and the annotated reference lists, be achieved with national consultants who met the "highest standards of academic and experiential qualification." These individuals were to be both "highly respected as scholars by members of the ethnic groups in question, and ... on the cutting edge of developments." He urged that as consultants were identified and brought to Portland, their presentations were to be videotaped for broad distribution throughout the District. At this point the list included Ivan Van Sertima, professor of Afro-American Studies, Rutgers University (social studies); Harold Courlander, scholar in the fields of African and Afro-American folklore (language arts); John Henrik Clarke, an educational psychologist who Hilliard referred to as an "eminent widely published historian" (social studies); Clyde Taylor, professor of English, Mills College (language arts); Julian Euell, director of Education, Smithsonian Institution (music); Nelson Stevens, prof essor of Art , University of Massachusetts (art); Michael Harris, Morehouse College, Atlanta (art); McKinley Burt, a local independent consultant, Portland (mathematics); and Beatrice Lumpkin, professor of Mathematics, Malcolm X College, Chicago (science). ${ }^{1}$

The testimony of these consultants was compiled and the process of transferring it into reference materials began in 1981. The first step included 
revisions for the Scope and Sequence documents. After preliminary changes in curriculum materials were made, "experts" with specialized knowledge in the field of multicultural education were called in as consultants. Contributors to the modification process represented a variety of ethnic minorities. One expert for the local community was Professor Darrell Millner of the Portland State University Black Studies Department. Under contract, beginning in 1982, with the District to provide technical assistance on Black History and Culture for the in-service program, Millner contributed a report entitled "Baseline Data- Afro-American History," which offered content additions in the social studies curriculum. ${ }^{2}$

Despite such strides toward multicultural curricular reform, another major racial crisis rocked the District in March 1982. More than ninety chanting demonstrators, angry about the site selected for the Harriet Tubman Middle School, forced the Portland School board to adjourn its meeting only twenty minutes after it began. Board members and the newly-appointed school superintendent, Matthew Prophet, the first African-American to hold the office, watched the demonstration impassively. "This just shows that people aren't going to sit back and watch them (the Board) destroy thousands of black lives," avowed Ron Herndon, co-chair of the Front, which coordinated the demonstration. BUF contended that the Boise site would force too many black students to be bused out of their neighborhood and that the site broke a promise, clearly stated in the District's Desegregation Plan, to put Tubman at Eliot School. About a half-dozen other black community organizations also took part. The Front had vowed to hold similar demonstrations and a series of one-day school boycotts to show its unhappiness over the Tubman site. The Board had decided on the Boise location that month, citing financial considerations. 
Moreover, they maintained that the Boise site would actually mean less disruption for black students. ${ }^{3}$

Board member Herb Cawthorne, the only black on the school board, stood during the demonstration and passed cups of water to hoarse chant leaders but did not take part in the chants. "The demonstration is a result of the board being completely insensitive to the black community," accused Cawthorne. "Some people can exercise power in a quiet meeting at a coffee shop, but the black community tried to use the process, and the board refused to listen." Cawthome was one of two board members to oppose the Boise School site. The newly-arrived Prophet indicated his preference for the Eliot site, but stated that he would implement the decision of the Board. ${ }^{4}$

Since the Black United Front had taken up the cause of quality education for black American students three years earlier, it had achieved a number of goals including the expulsion of Superintendent Blanchard, the hiring of the city's first black school chief, and the retention of a black consultant to help revise curriculum and improve minority hiring and placement in the city's schools. The controversy surrounding the location of the Harriet Tubman Middle School turned out in the Front's favor as the new facility was set up at Eliot School. Infused with strains of Pan-Africanism and Black Power and tied to local black nationalist associations, BUF had become a formidable facilitator, if not the cause of a growing sense of community racial empowerment in Portland. As a result, it began to wield more power in policy-making within the city's school district. The educational struggles of the late-1970s and early-1980s augmented the Black United Front's capacity to influence, if not control, staff selection, school location, curriculum and a proliferation of related committees in the early to mid-1980s. ${ }^{5}$ 
Although the Front possessed the strong support of most of the black community, the group emploited its influence and power to further an agenda that did not necessarily represent the community's diverse desires and perspectives. To a great extent, the Front had become a symbol of community empowerment and control that transcended the nature ot its particular demands. An indicator of this new-found clout was the choice of Joyce Harris, an educator and author of the baseline essay on language arts, as a paid liaison between the administration, the baseline authors, and the black American community. Harris, along with Ron Herndon, was a co-founder of the Black Education Center in Northeast Portland. Despite the important role of Asa Hilliard, the baseline essays reflected in part the ideology of the community leaders chosen to implement them. ${ }^{6}$

Responding to extreme community pressure and the growing power of the Black United Front, Deputy Superintendent James Fenwick promised in a May 1982 article in the Portland Observer, which possessed a predominantly black readership, that the final step of integrating the new multicultural curricula would soon be completed. By then, each elementary school possessed a team of principals, teachers, and library/media personnel who had been trained in the use of the "new curriculum documents" and would conduct staff orientation. Fenwick predicted that the new classroom materials would become models for districts across the nation to emulate. Furthermore, he felt confident that Portland students would have "a better understanding of the historical, scientific and cultural contributions of black people and other minorities in American society." Instead of relying merely on new textbooks, he argued, the District had taken greater control of multicultural education programs at the local and school level. While touting progress in the area of staff training, Fenwick conceded that realization of the complex goal of changing attitudes 
and perspectives and adding to the existing knowledge of District staff had not yet been met. $^{7}$

To implement curricula reform, Fenwick continued, Portland School officials had organized a thirty-three hour mandatory staff training program, begun two years earlier, to provide systematic training in multicultural education, human relations, and communication. The workshops received input from District staff, community members, Hilliard, and national consultants whom he recommended. Described by the Community Relations Department staff at Portland Public Schools as "an honest effort to improve inter-racial understanding among students, parents and the community at large," the program stressed staff training outcomes which enhanced " the self-esteem and cultural identity of minority students," and which improved racial understanding among all students. The training sessions al so sought to increase staff knowledge and understanding of African-American history and culture, the history and culture of other minorities, and the impact of problems created by social class. Fenwick passed on Professor Millner's warning that the first two years of teacher re-training was a learning experience that involved the formidable task of providing remediation in an area that originally should have been part of prepatory education. Such a challenge was exacerbated by the reality that teachers were of ten averse to pedagogic changes which imposed additional burdens on them. Moreover, the politicized nature surrounding the proposed amendments complicated matters further. ${ }^{8}$

Reflective of uneasiness with the manner in which curricular reform was occurring, Assistant Superintendent Edwin Schneider and Deputy Superintendent Fenwick sent a memorandum in June 1982 to Asa Hilliard in which they indicated that they were not clear where the curriculum revision process was going. District 
officials and the Curriculum Department staff had assumed that Hilliard's meaning of "baseline," a continually evolving and ambiguous concept, was in fact equivalent to the Scope and Sequence documents, the guides used by teachers for information, background, and structure. However, a visit by the primary consultant earlier that spring gave the Curriculum Department the impression that Hilliard's definition referred to complementary documents (that which would become the "Baseline Essays"), which would provide the fundamentals teachers presumably needed to teach a multiethnic curriculum. The two officials revealed that if their current perception of the "baseline" concept was correct, the District would adopt a plan to extend the complementary documents to the Scope and Sequence. First, visits and presentations of the major consultants would be taped and made a major resource for the staff training program. Second, Millner, who had been commended by Hilliard for work in developing a curriculum document for staff training, would be asked to assist in editing the written transcripts of the television tapes into a "coherent whole," which would be essential reading for all teachers. Finally, four African-American "concept papers" (synonymous and used interchangeably with "baseline essays," and "mini-major") were to be developed by the end of the summer, in math, science, literature, and social studies. Significantly, Fenwick's May article clearly and unambiguously enunciated the "renewed perception" of District officials without having had clarification by Hilliard about the specific definitions of the baseline essays. Such communication gaps may have been from the District's eagerness to respond to pressure from the African-American community. ${ }^{9}$

By early June 1982 the District had approached and received the willingness of Afrocentist scholar John Henrik Clarke to work towards the development of concept papers in the "various areas of multiethnic history," which he regarded as 
essential knowledge for all teachers. In their June memorandum to Hilliard, Schneider and Fenwick indicated the District's intent to utilize some of the other consultants recommended by Hilliard. The number of concept papers, the report instructed, would be determined by reason and balance in terms of the District's overall priorities, resources, and the availability of scholars to develop such papers. The model, to be used when a principal consultant "may be unable to undertake the task," was based on the development effort which had been used to create the materials for the math/science disciplines. In this process, lauded by Hilliard, school officials had used local consultants to do research on math/science topics identified as important by visiting scholars. Concept papers were then to be reviewed by these visiting consultants. Moreover, Schneider and Fenwick pointed out in their memo that additional background papers of a "less scholarly nature" could be developed by teachers interested in research in their respective areas of multiethnic education. In all these efforts, the Community Relations Department, which had primary responsibility for staff training, was to cooperate with the Curriculum Department. ${ }^{10}$

In a letter to the District four days proceeding submission of the SchneiderFenwick memo, Professor Hilliard presented his conceptual overview of the process. In his report he affirmed that the two basic goals of multicultural curriculum reform were equity in student achievement and equity in the curriculum. The basic strategies to achieve these ends were staff development, balance in student discipline, evaluation of pupils' progress, and the input of curriculum revisers to ensure cultural equity. Hilliard underscored that the DMAC's role was merely to monitor the process and advise, as only the Board was to make desegregation policy. ${ }^{11}$

The centerpiece of curricular reform was "the concept of Baseline." Hilliard affirmed that a "knowledge and skills baseline" was to be established. A 
comprehensive body of "content,"(essays) and bibliographic references for each curriculum area by major cultural groups was to be developed with consultative help from the "best local and national consultants" available, a standard which Hilliard emphasized continually. From this baseline, which was to be presented as an integrated whole, entries for the curriculum guide ( Scope and Sequence) would be taken, a needs assessment for teachers would be established, and the content to be taught to teachers would be provided. Although teachers proficient in the material would be exempt from further training, instruction was to be provided to those lacking knowledge of the baseline materials. Teacher training, which included materials other than baseline essays, was to be provided by local and national consultants. ${ }^{12}$

Under ordinary circumstances, "Baseline content," assumed Hilliard, approximated the academic prerequisites which allowed teachers, who presumably lacked the "appropriate cultural content" in their basic academic preparation, to have the foundation to use the Scope and Sequence documents. Moreover, it qualified them to teach specialized subject matter. Hilliard indicated that a mere citing of isolated facts or events associated with "cultural groups" would not be sufficient. Moreover, since the appropriate cultural content was not normally a part of a teacher's basic academic preparation, indicated Hilliard, a college level curriculum was to be offered to teachers to compensate for training deficiency. A second 'baseline' was to be established," the report instructed, for valid teaching strategies, classroom methodology. Teachers able to meet the District's achievement goals by their own methodology, Hilliard maintained, would not need further training. "In short, the content baseline is the knowledge that we want teachers to have."13 
In a report to Assistant Superintendent Hartzog in November 1982 that reviewed a recent visit to Portland Public Schools, Hilliard disclosed some of his observations. In clear and unmistakable terms, recounted Hilliard, the new superintendent had reiterated his and the Board's commitment to an effective multicultural education program. The chief consultant suggested that a momentum for implementation had been accelerated and stated that for the first time a status report of the completed work and future plans of desegregation planners had been presented to District executives. Hilliard observed that each of the presentations which he saw or had knowledge of was done with a "level of detail which should make it possible for the Plan to be executed efficiently." He expressed hearty approval for Millner's role as a consultant. Hilliard further affirmed that Millner's presentation, a conceptualization of the components necessary for an effective "baseline, illustrated "in a skillful and supportive manner," issues and questions about the status of the CDP implementation in a way that permitted clear positions to be taken by the leadership. ${ }^{14}$

In terms of his meeting with the DMAC, Hilliard's report centered mainly on the review of desegregation implementation. He had advised the committee to concern itself primarily with "results ... and to keep the monitoring of process to a minimum,"as he expanded no further on his meaning. The chief consultant proclaimed that the "Leadership Retreat," which occurred during this recent visit, was the "single most important meeting within the District since the beginning of the Desegregation Plan," and commented no further. Regarding the content of this significant event, he merely added that it povided the cornerstone for significant progress. Achievement gains, reduced discipline problems, improved community relations, and curriculum changes, Hilliard asserted redundantly, were attainable 
goals, given "vigorous and faithful implementation of what has already been planned."15

In January of 1983, Professor Millner released a document outlining his perception of what was necessary for the District to establish an effective baseline for multicultural training and education for teachers and students. This was an extension of the concept he had presented two months earlier, which was part of an evolving process that Hilliard had applauded. In reviewing the current status, the Portland State professor asserted that although the District had confirmed its commitment to the multiethnic/multicultural effort/product (me/mc), it had not stated specifically what students were to learn, nor did it offer a corresponding timetable during which this was to be achieved. Acknowledging the great role that instructors would have to play in the baseline effort, Millner warned that "teachers have more reasons not to upgrade me/mc skills than to upgrade them." Among them was resistance to the idea that they needed remediation, the reality that $\mathrm{me} / \mathrm{mc}$ had been forced on them, a lack of appreciation for $\mathrm{me} / \mathrm{mc}$, and the burden associated with acquiring these new me/mc skills coupled with other District responsibilities they faced. ${ }^{16}$

The failure of the District to articulate what students should learn, Millner argued, along with an inability of teachers to access resources, and the lack of a uniform approach, made it "difficultimpossible for teachers to ... plan learning experiences." These challenges, exacerbated by the short timeline originally outlined, he continued, rendered initial teacher training expectations unrealistic. It was not practical to expect teachers who were "products of 300-year tradition of one approach to $\mathrm{me} / \mathrm{mc}$ to be retrained into a more positive approach in two years." Millner suggested that the initial adoption of a "saturation model," the attempt to give the 
largest training dose possible to the largest number of teachers in the shortest amount of time, was necessitated by tensions between the District and community members during the evolution of the Desegregation Plan. The content of this teacher training program was negotiated by the Curriculum Department, DMAC, and BUF, as the latter groups exercised disproportionate power. However, he intimated that it should be replaced by a more precisely defined "developmental model." The initial plan, "the saturation model," of teacher training, Millner observed, focused on building awareness and appreciation of "me/mc" contributions and teaching strategies, but lacked the means for teachers to determine their needs, acquire "content expertise," and attain incentives for their involvement. ${ }^{17}$

The area of "curriculum development," declared Millner, experienced the most progress. Yet a major oversight of the initial plan was the omission of a "compatibility" component, as attention needed to be focused on those "elements and traditions inherent in 'mainstream' materials ... that function to subvert the new $\mathrm{me} / \mathrm{mc}$ material." Conceding that a sizable body of raw draft material appropriate for inclusion in the District Scope and Sequence had been developed, he suggested that "rough material" needed to be submitted to qualified consultants, local practicing teachers, and "community parties" for review and recommendations before being synthesized into Scope and Sequence documents. The infusion of this tremendous amount of material, advised Millner, required a carefully staged program of new $\mathrm{me} / \mathrm{mc}$ material in coordination with the establishment of District-wide student achievement objectives and measurements. ${ }^{18}$

Underscoring that teachers were required to provide multicultural instruction and principals were to evaluate them on performance, Millner argued that a criterion be set, "against which both student learning and teacher evaluation can be made." 
This, he indicated, would provide a context to conduct an evaluation of teacher needs and further curriculum development. Suggesting that modifications to the original plan might prompt "community skepticism" over the continued commitment of the District to the original goals of the CDP, Millner called for a clearly-articulated program with component coordination, and a timeline of objectives that would be conceived with full community "access, involvement and review." 19

Begun in September 1982, Millner's contribution refined effort towards a multicultural curriculum that had taken place over the past two years. But the centerpiece of the professor's "Concept Paper" was the baseline components. For the CDP to work, declared Millner, a "baseline" of knowledge and training in me/mc content was essential. It included the mutually dependent, and balanced interaction of an Awareness Baseline (teachers), a Curriculum Baseline (materials), an Achievement Baseline (students), and a Compatability Baseline (knowledge integration). Millner's document expanded upon these structural elements in generic terms, a design to allow for expansion into other pertinent $\mathrm{me} / \mathrm{mc}$ areas, i.e., other ethnic groups. However, it used the African-American experience as a prototype for implementation. This approach once again reflected the volatile racial circumstances of the District during that period, and the consequent mandate of the Board through the 1980 Desegregation Plan, indicating that the first priority was the revision of materials related to "Black multiethnic/multicultural goals."20

In terms of the Awareness /Baseline, instructed Millner, the District was to commission, through qualified authors, essays in Math/Science, Social Studies, Literature, Oregon and General Afro-American History, and Creative Arts. The time-frame for completion of these essays was September 1983. In a climate of extreme and mutual distrust between the Black United Front and the District, a list of 
qualified local consultants had been provided to the Curriculum Department by "various community representatives," the BUF. This was a change in direction from that prescribed by the CDP, but still within the range of reasonableness. This list of individuals was to be reviewed by Hilliard, who was to be asked to recommend additional consultants from the national arena. ${ }^{21}$

Recommended local consultants included Joyce Harris, William McClendon, McKinley Burt, Jasper Hormound, and Kamau (Nathan) Anderson. While they were endorsed by the Front and admitted by District officials, this group of locally active individuals garnered varying degrees of acceptability from Portland school officials. Nevertheless, the District seemed to have little choice since it contained too few African-American teachers to use as consultants and the politicized environment in which the Front exercised influence required them to be black. Moreover, many teachers were reluctant to immerse themselves in politicized issues. Millner also suggested the creation of a "baseline library" to complement the District's own collection of materials, and that support seminars and the development of "Inhouse Content Experts" be developed in cooperation with the Black Studies Department at Portland State University. The training program to develop these local "content" experts would include areas ranging from "African Involvement in the Ancient World" to "20th Century Afro-American History/Issues."22

The Curriculum Baseline, instructed Millner, would use consultants to review and modify Scope and Sequence material for the infusion of "Afro-American material." These were to be dispersed to "local practicing teachers, community members, etc." The DMAC curriculum sub-committee was to review recommendations, which would include the "continued involvement of local consultants ... as well as necessary additional consultant (national) and District 
personnel." Through this process supplemental lesson plans supporting the new "Afro-American" additions to the Scope and Sequence would be prepared. Millner was to preside over this endeavor, presumably as a counterweight to Ron Herndon, who as leader of the Front wielded tremendous influence choosing authors for the essays. $^{23}$

Insofar as the Achievement Baseline was concerned, the focus of $\mathrm{me} / \mathrm{mc}$ learning was to include extensive "exposures" to a diversity of cultures (grades K-3), emphasis on "non-stereotypical" instruction in social studies(grade 4), slavery studied from a multicultural framework (grade 5), black biographies including figures in African, Afro-American, and Oregon history (grade 6), Afro-American involvement in the American Revolution and the Civil War/ Reconstruction (grade 7), the Civil Rights Movement in 20th Century America, Oregon Afro-Americans, and Contemporary Africa (grade 8), and the development of elective offerings in the Afro-American experience (high schools). Millner recommended that whenever a measurement plan of the Afro-American baseline began, that it be in a small cluster of schools so that field testing and adjustments were possible. He suggested that the "Needs Assessment" of teacher training could be based on "results of levels testing in me/mc achievement." The integration of the Compatibility baseline as well as the total me/mc baseline, argued Millner, would be enhanced with the employment of an individual within the District's Curriculum Department, who possessed expertise in the area of Afro-American experience. ${ }^{24}$

The response to Millner's report was largely positive. However, it required a substantial undertaking in a large school system bridled by finite resources. Moreover, some of Millner's ideas met with disapproval. For example, even though he had made suggestions for the efforts of some local consultants in 
preparing Scope and Sequence materials, local experts were put off by the removal of group training sessions for teachers as a means of remediation. Furthermore, Millner's plan would curtail the influence of the Black United Front and its supporters. Consequently, the District did not implement the comprehensive approach to curricular reform outlined in Millner's report, and instead focused on teacher training and the baseline essay effort, an indication of the continuing influence of BUF. ${ }^{25}$

Following the 1983 release of the District's first set of essays, which included Millner's "Baseline Data and Afro-American History," major controversy erupted. In a letter to the Oregonian, Susan C. Karant-Nunn, a professor of latemedieval European history at Portland State, admonished Superintendent Prophet and the Board to "study with healthy skepticism the recommendations of Professors Darrell Millner, Asa Hilliard, and others." Conceding that historical "inaccuracies and comfortable stereotypes" should be amended, Karant-Nunn charged that the "attempt to bolster the self-esteem" of people "through the further falsification of the past" was a disservice to all. While expressing hope that members of DMAC would possess the capacity to evaluate the credibility of proposed curricular changes, Karant-Nunn maintained that "history is not a weapon. It is a means of understanding ourselves and others." The letter precipitated a defamation lawsuit by Professor Millner, and subsequently settled out of court without damages. ${ }^{26}$

In an increasingly contentious environment during May 1984, Millner and the group of local consultants, except for William McClendon, pressed forward to release a proposal entitled "Comprehensive Staff Training For Incorporating African-American Curriculum Materials Into Language Arts, Mathematics, Science, Social Studies, Music, and Art." Oriented towards all staff and parents, the proposed 
training sessions were intended to prepare teachers to " create, select and use AfricanAmerican materials routinely" in the existing curriculum. Based on recommendations from national and local consultants, information was to "be presented to participants (teachers) in concise and systematic training modules that will reach students quickly and with observable results," via lesson plans. ${ }^{27}$

The training was to be delivered primarily by local consultants "previously endorsed by the DMAC," which implied BUF support. Kamau Anderson and McKinley Burt were to assist in the development of math and science, Harris was to oversee language arts and curriculum development, Hourmond was in charge of testing and evaluation, and Millner was to aid with the evolution of social studies. National consultants were to "either produce or review training materials." At the time, these consultants included Beatrice Lumpkin (math), ,Clyde Taylor (literature), Ivan Van Sertima (history), Julian Ewell (music), Nelson Stevens and Michael Harris (art), and Hunter Adams (science). ${ }^{28}$

The baseline essays, the proposal instructed, were to be the texts used in the training, and a pre-programmed approach, based on prepared lesson plans drawn from the essays and coordinated with Scope and Sequence and continuum materials, would be employed. Under the coordination of a liaison, a seven-week training program utilizing these local and national consultants would be conducted using the staff from seven target schools as identified in the Desegregation Plan. The training, "practical in orientation," was to be followed up with evaluation sessions based on student performance and teacher compliance with new materials. Yet none of this would materialize. Millner's significantly different approach to the multicultural efort would, increasingly, separate him from the group of local consultants. Moreover, 
the tension between the local consultants, who were an extension of BUF, and teachers, would render real challenges to any training effort. ${ }^{29}$

In his Report of Consultation, presented in June 1984, Hilliard reviewed the District's efforts over the past four years. "When I came to the District," declared the chief consultant, "the budget for the desegregation effort, some $\$ 3$ million dollars per year, I was told, was already allocated to implement specific parts of the plan." Hilliard affirmed that the main parts of the effort were well underway. He disclosed his belief that too little of the available resources went "to produce long-term changes in the system itself,"presumably the multicultural curriculum effort. Instead, asserted Hilliard, the lion's share of the budget was consumed in an "enriched staffing formula" for the ECEC, an undertaking whose priority he disagreed with. ${ }^{30}$

Despite such criticism, Hilliard observed that committees such as DMAC and the DCC were already in operation and a major effort to revise the curriculum guide was on the brink of completion. He argued that students would learn more and better as a "result of our efforts," and what they would learn would "be accurate, salient, and meaningful for all groups served by the schools." While the District had already initiated a process to revise its Scope and Sequence requirements by 1980 , the chief consultant argued, few teachers possessed the proper training to be "aware of cultural and ethnic prospectives and materials" that had become more abundant in recent years. He applauded the process and product of the math and science effort, subjects which Hilliard suggested had prestige value and contributed to "motivation and self-concept in a special way" for minority pupils if "represented appropriately."31

Because such information was "vital to the development of self-concepts of minorities and scientific accuracy for all children," Hilliard maintained, he re- 
affirmed his recommendation to have "the highest qualified experts in the nation" help revise the Scope and Sequence documents. Yet later in the same document the desegregation consultant recommended that the remaining revisions on the Scope and Sequence be reviewed by "local consultants with special expertise in African/American prospectives" and that they be used as trainers for demonstrating baseline content to teachers. Similarly, in an informal letter from Hilliard to Prophet soon after this memorandum to the Board, the chief consultant underscored that national consultants should review any final products developed locally to ensure relevancy and accuracy. This apparent contradiction and capitulation on Hilliard's part, which characterized these and many other documents released by the chief consultant, may have been a result of the disproportionate force that the Front and its allies wielded in District affairs. ${ }^{32}$

Later that month, a bemused Assistant Superintendent Edwin Schneider communicated to Superintendent Prophet in a letter provided to Board members days later. Schneider confessed that he had been unable to provide a clear definition of "baseline" at a Board meeting days earlier. That was because it had "changed drastically" over the past three and a half years, during which it had been "discussed and described in the writings" by the prime consultant. Schneider complained that Hilliard's last written statement, created in June 1982, required a "mini-major" college level curriculum to rectify perceived shortcomings in teachers' formal training, a great undertaking which "we regarded as outside the scope and goals of the District." ${ }^{33}$

Schneider claimed that the baseline term had been "described variously" to mean a prepatory college level curriculum for teachers, reference books for them to read as background, pedagogical strategies for instructors who were presumably not 
teaching successfully, and curriculum content for students. Schneider, who oversaw the Curriculum Department, pointed out that Professor Millner had developed a revised definition of baseline. The 1983 "Concept Paper," informed the assistant superintendent, required one year of negotiation between the Curriculum Department, BUF, and Hilliard and thereafter became the District's working definition." However, Hilliard's 1984 visit revealed that disagreement once again had surfaced on the meaning of baseline. At that time the chief consultant acknowledged that he did not "know what "baseline' looked like but he would know it when he saw it." It may have been that Schneider, a Blanchard loyalist, resented Hilliard, not only for his "questionable leadership" through the multicultural curriculum effort, but for his association with the Black United Front, the organization who "rode Blanchard out of his position," before his death immediately afterward. On the contrary, Millner was seen by Schneider as a colleague, whose aims were more suited to the District's, and might serve as an explanation for the greater reception of the former. ${ }^{34}$

The assistant superintendent noted that in the process of developing some of the baseline essays, community agreement on acceptable writers had not been attained. Despite this fact, he indicated, the District had hoped to have the essays completed by the end of August 1984, an impossibly high expectation. ${ }^{35}$

In an attempt to resolve the confusion surrounding the term "baseline," Prophet asked Hilliard three days later to provide a definition in written form. The chief consultant responded in early July to clarify "our old friend 'baseline." He stated that the term simply referred to the minimum academic requirements that a teacher would need to use the new material in the Scope and Sequence documents. Acknowledging the lack of support by the District for his proposals for extensive staff development, Hilliard deferred to Millner's plan for baseline essays. "They 
were to be based upon national consultant input with a review by local consultants," Hilliard now explained. He indicated that the essays would contain information and bibliographies which could be used for staff development. Professor Hilliard concluded by acknowledging that Millner's Baseline Data and Afro-American History, the document that precipitated a major controversy a year earlier, provided an excellent example of "what is missing in the other curriculum areas."

In a memorandum to the Board in late July 1984, Superintendent Prophet clarified the definition of baseline that Hilliard had outlined. Prophet declared that Millner's history essay would be adapted as the model "baseline" document. Furthermore, DMAC's recommendation to employ local consultants to develop "baseline essays," in consultaion with national consultants recommended by Asa Hilliard, would be accepted. Local consultants, moreover, would develop related lesson plans to guide staff training in multiethnic elements of the involved disciplines. DMAC, which was originally designed to encourage broad participation in continuing desegregation efforts, had narrowed its focus since 1980. The meetings were in northeast Portland, in predominantly black neighborhoods. The Front, which increasingly saw the DMAC as the machinery giving them access to the District and policy change, brought more people, and came to dominate the DMAC, as it became their primary focus. At least two predominantly white organizations that were to be represented on the committee, along with groups representing Spanish-speaking and American Indian communities, had stopped participating. Millner was now mandated to develop a second baseline essay on the black experience in Oregon, and the baseline essays would be issued to all teachers for background reading. Conceding Hilliard's point that there was a long-term need to 
examine staff training in "baseline" for all schools, Prophet nevertheless affirmed his belief that the steps he had outlined would be responsive to such concerns. ${ }^{37}$

A progress report that Superintendent Prophet released in January 1985 asserted that modifications had taken place in implementing the CDP. The document indicated that Chief Consultant Hilliard's recommendation that "we set improved student achievement as the District's main goal, " a more narrowly-defined goal than the prime consultant had outlined to district officials two years earlier, prompted the Board to adopt such a policy. Moreover, the superintendent had recently affirmed that curricular improvement was as primary a goal as student achievement. Indicating that there had been "many solid successes as a part of the desegregation effort," Prophet argued that all children were "fully capable of learning," which presumably challenged the belief systems of some teachers, and "that [a] curriculum can be developed which is fair and equitable. ${ }^{38}$

Prophet also rejoiced in the dramatic reduction of suspensions among African-American students. For this, his report credited the work of the curriculum consultants, although it seems that it was the adoption of more racially balanced discipline policies which actually reduced the suspensions. The superintendent acknowledged the completion of the District's Scope and Sequence documents in most disciplines as a "major accomplishment" of the CDP implementation during 1984. Appropriately, the principal of predominantly-black Tubman Middle School soon complimented local and national consultants for useful workshops on multicultural education. ${ }^{39}$

Chief desegregation consultant Hilliard expanded on the two overarching goals, student achievement and curricular improvement, in a letter to Assistant Superintendent Hartzog the following July 1985. Regarding student achievement, 
Hilliard stressed "the elimination of the achievement gap between majority and minority students." Regarding the curriculum, he emphasized equity and accuracy in the content. Citing the success of Portland's "results-oriented focus," Hilliard challenged the idea that minority or poor children could not master high-level academic work. He denounced the idea that there was little need to continue changing the curriculum when "we now have in hand revised curriculum guides" infused with "solid" multicultural material. Responding perhaps to suspicions that the Black United Front had placed a dominant role in choosing curriculum consultants, Hilliard asserted that the mentors had been identified "solely on the basis of their track records in their field and not on the basis of their speculation or their personal relationships with anyone." Portland Public Schools, he maintained, had assumed a national leadership position in the field of curriculum development. Yet such assertions were hard to substantiate in the face of the local consultants retained by the District. ${ }^{40}$

Hilliard also addressed criticism from the white community regarding whiteethnic representation within the curriculum. He cited "years of segregation, general oppression and ... neglect" as the cause of the "inequitable educational opportunity and the giant gap in achievement" between minority and majority children. Such a situation, he argued, required "the special treatment of target groups in a desegregation effort, as the gap would never be closed, unless this treatment was afforded Blacks and other traditionally excluded groups." Invoking notions of faimess, the chief consultant argued that support for students "who are at risk for failure ... must not be impeded by imposing requirements that 'all' children be offered similar remedial services" before target groups were served. ${ }^{41}$ 
Supporting the campaign for this notion of remedial service, the Cleveland Principal's Multiethnic Committee released a packet to the principals in the Cleveland Cluster in the Summer 1985. Its general purpose was "to create some useful resources" to support the principal's efforts within this area. In it the committee suggested that multiethnic themes helped all students identify more fully with the educational process. By "emphasizing and carefully selecting" curriculum content, students would be afforded opportunities for "building a positive self-image and pride." Among the panel's many suggestions aimed at realizing "a spirit of justice and equal opportunity," was the proposal that multiethnic education depict all humans as "strong, worthy and capable." The group encouraged the analysis of inter-group tension and conflict objectively and with "emphasis upon resolving our social problems," as "misconceptions, stereotypes, prejudices and other adverse feelings which limit the awareness and understanding of the beauty of cultural diversity" should be dispelled. ${ }^{42}$

Such assumptions regarding minority studies may have contributed to Multicultural Coordinator Darrell Millner's departure from the Program in 1985. Harris, Herndon and others had accused Millner of foot-dragging, an allegation they presumably equated with the belief that Millner focused too much on the American experience and not enough on the "Af rican and African-American experience." In addition, officials such as Carolyn Leonard, an evaluations specialist in the desegregation program, believed that Millner had never learned how to work within the public school system. Millner, in contrast, continued to assert that the baseline essays contained too much controversial material and that the mandatory retraining sessions with experts "was not going to be effective." 
Later in 1985, the District selected Leonard to fill Millner's position, but without his title and status as director. Leonard had no special experience in curriculum design, but possessed a substantial work history with the District, experience in the local black community, and formal membership in the Black United Front. Upon coming aboard, Leonard later indicated, draft copies of the essays were in "community hands" and out of her control. Af ter reading them, she would later recall, she was troubled, as she could not evaluate their accuracy and "the whole issue was deeply politicized." Moreover, the Board wanted to show its good faith and move forward. "There were serious time constraints," remembered Leonard. Harris would remember things differently. "If at any point the District felt that it didn't control the essays or was unhappy with their content," recalled Harris, "why didn't it fix the problems, or stop the process?" Despite the gap in top administrative leadership and a climate of contention and pressure, the Portland Public School edited, published, and distributed a draft form of the African-American Baseline Essays to selected teachers and administrators during this period. ${ }^{44}$

Plans for the adoption of the essays called for a large teacher meeting within each high school cluster area with presentations of the materials by expert scholars in each curriculum specialty. The first such session was held at Jefferson High School, but tumult ensued at a cluster meeting at Grant High School later in the year. Leonard arrived at the meeting to find the 300 or so skeptical teachers at the back of the auditorium. When she asked them to move to the front, one male teacher began yelling, and it "went downhill from there."4s

The Grant meeting appeared to present a crisis for teacher acceptance. As a result of that fiasco and the Black United Front's sponsoring of a one-day boycott of schools to protest the District's failure to make bigger gains in minority student 
education, a reluctant Superintendent Prophet created the Multicultural/Multiethnic Education Task Force (METF) in 1986. Leonard chaired the task force, which included Herndon, DMAC chair Rahsaan, two directors of instruction, and several others. The new panel discussed ways to salvage the essay implementation process and improve the multicultural curriculum, yet the results were questionable. Harris indicated that areas agreed upon at METF meetings were later disregarded. Rahsaan and Herndon would resign in disgust, the latter urging an end to all large cluster meetings because "the process had been seriously mismanaged by Leonard and others." The administration abandoned the large meetings. ${ }^{46}$

In March 1986, Halim Rahsaan indicated that material used in the multicultural training program had stirred doubts among teachers and administrators and would probably not be used in the classroom that year. "There's really been a reluctance on the part of a lot of teachers and administrators to believe this information," observed Rahsaan. He claimed many administrators, especially the mid-level directors of instruction (DOls) who oversee the District's nine high school attendance areas, did not accept the validity of multicultural training. Suggesting that many of these DOIs had not even read the essays, Rahsaan argued that "if they don't support it, principals aren't going to support it." To increase acceptance of the program, Rahsaan proposed to Superintendent Prophet that the District begin conducting human relations sessions for administrators, teachers and other educators who present the materials. Rahsaan further asked the Board to establish an evaluation team to look into a number of problems surrounding the on-going training program. He argued that there was no systematic approach toward developing lesson plans, little coordination from the District's central office, and no program for evaluating the effectiveness of the training. Moreover, he complained that the District 
had not completed and disseminated the "baseline essays." Beset by political tensions and delays from the beginning, the CDP appeared to be in serious trouble. ${ }^{47}$

A report generated by the District's Research and Evaluation Department and Management Information Services during the 1986-1987 school year addressed the controversies of curriculum reform in both the school system and the greater community. Reiterating that "all students can learn," the document affirmed that the District rejected the "suggestions in some quarters" that the "observed differences" in the achievement levels of students of "various backgrounds are inevitable." It conceded that the "barriers to high levels of achievement" were surmountable, not with "simple solutions," but with ones which accounted for and addressed the underlying, "complex and pervasive" elements such as the influence of home, community, peers, and school environments and cultures. However, the report's focus on the gains in performance of minority student groups, and the ways that the District's curriculum addressed "appreciation and knowledge of one's own culture or the cultures of others" reflected, once again, the prevailing paradigm by those in the community and the curricula reform effort that there was a relationship between "good" historical role models and student achievement. ${ }^{48}$

In a memorandum to Assistant Superintendent Ernest Hartzog in January 1987, Hilliard charged that the "availability of consultants of first choice," as the reason for delay with the multiethnic curriculum. He informed Hartzog that these consultants should continue to be involved in the training process for the District. The chief consultant, however, indicated that he had met with the local consultants whose efforts had "helped guarantee the quality of content and editing, "for the curriculum documents. In all cases, instructed Hilliard, the "local consultants should be a part of a final rigorous review." These instructions contributed to the 
long pattern of contradictory statements by the chief consultant regarding how to ensure accuracy of curriculum materials. ${ }^{49}$

Despite Hilliard's attempts to explain delays in curriculum reforms, the DMAC complained to the Board in June 1987 that the Portland School District had still not implemented a multicultural curriculum and had reneged on commitments to METF, the task force established to review the process. Moreover, DMAC charged that in the past two years many of the group's recommendations concerning black student suspensions had received little or no response from the District. It may have been that Superintendent Prophet had begun to hold the reins of power during this period, and thus exercise independence from BUF and Herndon, a significant turning point. Prophet conceded that the committee's recommendations were "excellent," but argued that the District was not obligated to follow all suggestions made by any group. This was a tremendously decisive period, one in which the District's control over the multicultural effort was galvanized, and the force of the Black United Front and its machinery began to wane. ${ }^{50}$

In a climate of decreasing power for the Black United Front and its appendages, Halim Rashaan, chair of DMAC and a member of METF, objected to Prophet's apparent attempt to marginalize the impact of African-American community imput. Rashaan declared that when the task force had been created in 1986 , the District had agreed to allow task force members to review curriculum documents outlining contributions which ethnic groups had made in a variety of disciplines "from a historical and contemporary perspective." The 25 -member force, he continued, was also supposed to review the scripts used by national consultants who wrote the documents prior to the videotaping of scripts that would be used to train teachers. "These things," complained Rashaan, " did not occur." He maintained that 
task force member Ron Herndon resigned in May 1986 because Coordinator Leonard did not respect "written commitments made with the Task Force."51

Despite rampant dissension over the multicultrual curriculum reform, Asa Hilliard nevertheless suggested in July 1986 that the completion of AfricanAmerican baseline essays had gained the District a "solid national recognition," and observed that at least five national black organizations had endorsed the Portland innovations. All the city needed to do, he argued, was offer a "high-quality" teacher training program so that the curriculum could be implemented. Yet consultant Darrell Millner's warnings and the uninterrupted resistance of the majority of Portland Public School teachers indicated the unrealistic nature of Hilliard's assessment. In a New sweek (1991) article, Leonard would reveal that only 20 percent of the city's teachers used the baseline essays comprehensively in their classrooms despite the fact that they had been available for four years. In May 1987, Hilliard may have sought to extricate himself from the role he had been playing in Portland when he advised Assistant Superintendent Hartzog that "my services be utilized on an 'as needed' basis." 52 


\section{CHAPTER 4}

\section{THE RESPONSE TO PORTLAND'S AFRICAN- AMERICAN}

\section{BASELINE ESSAYS}

Soon after Asa Hilliard's graceful departure from the Portland multicultural curriculum reform effort, a storm of criticism thundered around Portland Public School's African-American Baseline Essays. At the heart of the documents, wrote journalist John Leo of U.S. News and World Report in November 1990, was "an unlikely claim" that consumed more than 35 percent of the curriculum's text: Ancient Egypt was a black nation. To gloss over black success, the Baseline Essays maintained, "Europeans invented the theory of 'white' Egyptians who were merely browned by the sun." Experts, asserted Leo, did not seem to support this view. Of the seven Egyptologists he phoned at random around the country, all seven, who spoke on the condition of anonymity, proclaimed this assertion to be "completely untrue." "It's politically too hot to say this [in public]," said one, and added that there was a "small germ of truth to the theory: A number of blacks from the south moved freely and easily in ancient Egypt, which was not a race-conscious society"1

The argument that Egyptians were black would seem to position blacks as slaveholders of the ancient Hebrews, observed Leo, who pointed out that the guides "finessed" the issue by describing the Hebrews as wanderers who entered Egypt to escape famine and stayed on as "guest workers." If anything, he continued, the Baseline Essays were "restrained by current standards" of Afrocentric theory, because militancy had "ratcheted up several notches" in recent years. The curriculum, offered Leo, split the black community between those who were willing to go along with the "systematic propagation of fantasy history and bizarre theories" 
and those who were not. Referring to a recent Afrocentric convention in Atlanta, he suggested that it did not attract black scholars of "the first rank," but it might reach the point where they " will come under increasing pressure to fall in line." Leo avowed that urban schools were in danger of adopting a "Tawana Brawley theory" of history, in which facts do not matter, only resentments and group solidarity. ${ }^{2}$

The Baseline Essays, observed Leo, called for "understanding, respect and appreciation for the history, culture and contributions of other groups." Yet the attacks on Europeans and Western civilization began on the very first page, in an introduction to African art, and continued throughout the text. He suggested that this "tone of smoldering resentment" might increase racial group solidarity and vent frustration, but could not see how such a curriculum would prepare black youngsters for entry into the job market or help fit them into the broader society. The Afrocentric curriculum, he observed, was usually presented as an attempt to develop pride in black children by giving them a racial history. However, Leo questioned what kind of pride and self-esteem were likely to grow within black children from the use of a "false history" and how much more cynical would they become if they discovered that they had been "conned again, only this time by Afrocentrists."

The following week columnist Steve Duin, of the Oregonian, blasted the essays. After enumerating a littany of "bogus claims" contained within, Duin pointed out that some of the "preaching" in the Baseline Essays had been derided by more balanced historians with whom the Oregonian reporter conferred. Ray Sealey, an expert in ancient Greece at the University of California at Berkeley, dismissed the assertion within the essays that the Greeks owed most of their culture to Africans as "utter nonsense." Similarly, Duin, through his interviews, cited the rejection of such claims by Brendan Nagle, an associate history professor at the University of 
Southern California. The Greek creation of math and science, insisted Nagle, was "entirely their own, as is their philosophy."

Other scholars also attacked the notion that Ancient Egypt had been a black nation. "Totally false. That's a myth, based on the flimsiest kind of evidence," proclaimed Professor Afaf Marsot of the Near East Center at the University of California at Los Angeles. “The Egyptians were a mixed population, as all Mediterranean people are mixed. Every Egyptologist will tell you what I'm telling you." Frank M. Snowden Jr., a classicist at Howard University and author of Blacks in Antiquity, was most doubtful about painting ancient Egypt black. Miriam Lichtheim, an Egyptologist, was equally dismissive, unequivocally denouncing the idea that Egyptians were black. And Mark Van De Mieroop, a professor of MiddleEast Studies at Columbia University, observed that " $[w]$ hen we get into the racial designation of ancient people, we go back to the '30s. That's the Nazi's influence on scholarship, when they were trying to argue that there were no Semitic roots in Egyptians.""s

Despite the flurry of complaints from noted scholars, Portland AfricanAmerican activist Joyce Harris, an author of the Language Arts essay, defended the essays' veracity. Harris explained that "you siphon out what is useful to you ... For years people interpreted our history, our culture. Where was the hysteria when our children were taught Africa was a dark continent?" If the Baseline Essays were conceived with the "admirable goal" of filling in the vast blanks of our knowledge of black culture, continued Duin, "they of ten lapse into the hysterical." Duin noted that the social studies essay on Cleopatra by John H. Clarke professed that the "African queen was of mixed African and Greek parentage. If she were alive today, there is 
no way she could pass for Caucasian. If living today, she would probably be living in one of the black communities in the United States." ${ }^{6}$

"What segregationist claptrap are we preaching?" thundered Duin, "that a woman who can't 'pass for Caucasian' would, by necessity or choice, live in a black community?" The Baseline Essays, he argued, stressed black culture at the expense of all others, mixing political statements with historical insights, while resurrecting "segregationist history." Duin conceded that some historians had "skipped lightly" over what many disciplines owed to the many cultures in Africa. Yet the problem with the African-American Baseline Essays, he suggested, was not their attempt to restore black culture to its rightful place in the historical equation, but the "bending" of "history past the breaking point and lying under the pretense of multiculturalism."7

Bill Graves, another columnist for the Oregonian, observed in an adjoining article that a growing number of historians across the country felt that students in African-centered history courses, such as the African history class at Jefferson High School, were learning things that were not true. Much of the criticism, observed Graves, was being leveled at the Portland School District's African-American Baseline Essays. Long a model, he continued, the essays were becoming a target for critics who suggested they "promote a narrow, distorted view of history."

Burton Beers, history professor at North Carolina State University in Raleigh, and other historians, observed Graves, believed that African-centered courses were "making questionable claims and shifting instruction from one narrow perspective to another." The baseline essays' claims were "nonsense," offered Arther Ferril, a prof essor of ancient history at the University of Washington. It was not likely that the native population of North Africa was black, he offered. Frank 
Norick, an anthropologist for the Lowie Museum run by the University of California at Berkeley, denounced the idea that Egypt owed its civilization to African blacks. Similarly, assertions in the essays that Cleopatra was black or that the mathematician Euclid was Egyptian were "flat-out wrong," asserted John Nichols, professor of classics and history at the Universtiy of Oregon. Cleopatra was a Macedonian queen and member of the royal Ptolemy family and Euclid a Macedonian, he countered. ${ }^{9}$

While historians widely endorsed a broader, multicultural approach to teaching history, observed Graves, many objected to what they saw as a distortion of African history to boost ethnic esteem. "Ethnic groups putting their ethnicity ahead of the welfare of the nation is not a good thing," Norick said. "We are all Americans, after all." Nichols indicated that historical distortions undermined the worthy efforts of people trying to make Americans more aware of African contributions to the world. "It's demeaning to the culture they are trying to defend." 10

However, those who researched and compiled the Baseline Essays were not retreating. They defended the accuracy of their works and charged that critics represented "defensive white academics," who wanted to protect a narrow "European-centered version of history." Graves quoted DMAC chair Halim Rahsaan as claiming that only white scholarship "carries weight in American society. There is always going to be a problem as long as Europeans try to define everyone's history." The Oregonian piece also provided Asa Hilliard with a platform. "This is a very broad-based attack, and the attack on Portland's curriculum is only part of it," declared Hilliard. "It is clear that somebody doesn't want black people to know anything about black people." 11 
In a similar attack in the Oregonian on the veracity of the African-American Baseline Essays, David Coomler, a resident of Northwest Portland, dismissed, in a letter to the editor, the "fanciful allegation within the documents" that ancient Egyptians "used their early planes for travel, expeditions and recreation." Coomler, who affirmed that black students deserved the best education that can be provided, pointed out that in the face of recent budget cuts, "it might be wise to start with those who authorized this pitiful book for use in Portland's school system." 12

Later in November 1990, Education Week ran an expose in which Frank J. Yurco, an Egyptologist at the Chicago Field Museum elaborated on the content of the social studies portion of the Portland African-American Baseline Essays by John Clarke. Yurco quoted Clarke's closing paragraph as follows:

Now that we[black Americans] are becoming more aware of our history and how to use it as an instrument for our liberation, we know that we are the only immigrant group that was invited here. Those who invited us waited anxiously for our arrival. They sent large ships to bring us here, manned by well-armed thugs. We faced no unemployment problems, there were plenty of jobs waiting for us. The jobs that we did helped to make America.

In a seven page evaluation, Yurco suggested that the social studies packet was "the worst one reviewed by me thus far." Clarke, he charged, was "clearly one of the extreme revisionists, and his biases shine forth in both his writing and his bibliography," eschewing "non-Afro-American Egyptologists and depending on only 
Afro-American writers for his sources." What resulted, he continued, was "a melange of misinformation, inconsistency, outright fallacious information, halftruths, and outdated information." Such distortions of history, "partial and partisan views, and unscholarly use of sources," asserted Yurco, destroyed the value of the packet. It would be a "gross disservice" he suggested, to use such a curriculum for teaching, as children would receive a "warped and biased account of history."13

The storm of criticism carried on for more than a year. In October 1991, Richard G. Garrett, a math teacher in the District with seventeen years of experience and a former university professor, proclaimed that the "flaws" in the available Baseline Essays were "obvious to the impartial reader, adding to mistakes of the past." Suggesting that the scholarship was both eccentric and pedestrian, Garrett assaulted the belief that contemporary racial and ethnic groups were in competition for history. "The essays assert the cultural pre-eminence of Af rica," argued Garrett, and "claim for it the treasures of history." But by doing so, he maintained, they promoted cultural stereotypes. For example, the essays claimed that the "European cultural base" focused "upon the physical universe," while the African focused "upon symbolic essences." Commenting upon the underlying theme within the essays that ancient Egypt was "a black nation," the "greatest nation the world has ever known," the teacher intimated that such assertions were not the products of scholarship, but of contemporary conflicts, of making history-as the essays proclaim-an "instrument of "liberation." Garrett insisted that the essays "reproduce, even magnify, the very mistakes they should have corrected" and concluded that "they are an albatross, and ... should be scrapped." 14

In February 1992, Oregonian columnist Steve Duin asserted that the baseline essays were "politically correct, not educationally sound," as the final 
selection of authors for these essays had been heavily influenced by the Black United Front. Duin contended that Darrell Millner had left the program out of frustration because the essays were as insensitive to the values and backgrounds of teachers as some of those teachers had been to minority students. He reported that Carolyn Leonard, who replaced Millner, defended the Baseline Essays against all calls for revision. When asked why the African-American curriculum condemned Europeans for slavery but overlooked the participation of African nations in this "Arab invention," Leonard explained that the media were so filled with negative information about Africa that the essays saw no reason to add to it. While Leonard decried generalizations about African-Americans, observed Duin, she proclaimed that white Americans did not "really want a united America or they would have invited everyone to the table. I don't see European-Americans reaching out to learn anything. If they want to get involved, they want to take over. They don't want to listen."15

The following month, Joe Uris, a.Northeast Portland free-lance writer and sociology and history professor at Clackamas County College, addressed the essays in an Oregonian piece entitled "Fighting Words." Although Uris defended the need for an "honest, significant and inclusive curriculum," he argued that the AfricanAmerican essays were not a step in that direction. While Superintendent Prophet, an exponent of "role model" history, [see Appendix B] declared them to be accurate, effective and well-received in Portland, Uris observed that the reaction from a number of District teachers and curriculum experts had ranged from "lukewarm acceptance to outright hostility."16

While the idea of broadening the scope of the curriculum to reflect cultural diversity and similarity was certainly defended by teachers, Uris observed that many 
Portland teachers characterized the essays as "poorly reasoned, ethnocentric and culturally stereotypical," suggesting a "single interpretation of the African-American experience." Uris reported that teacher focus groups in early-1992 indicated a concern about the essays' accuracy and a desire for more training, research and planning. He noted that many instructors used the essay content with which they were comfortable and complemented it with their own multicultural material. Uris pointed out that the demand on teacher time multiplied as each "trendy issue requires new material." Without a clear signal from administrators, some teachers saw new programs as fads. ${ }^{17}$

Persistent teacher resistance, contended Uris, was one reason why some in the Portland black community doubted the District's commitment to both the essays and multicultural education. Sheriann Haggar, a DMAC member, told the writer that Prophet could make the curriculum effort happen. Instead, she argued, the essays sat on the shelves because many teachers felt that the District was not committed to the program. Although Uris urged open debate over the Baseline Essays, he concluded that there were serious problems with the materials. Their style, he asserted, was "didactic, confrontational and talks down to the reader." The major irony of the essays, he continued, was that in focusing on Egypt, well-known and valued by the West, the essays downplay other African civilizations, whose arts, trade and technological skills were far more egalitarian. Perhaps the worst fault, insisted Uris, was that the Afrocentric materials were too accepting of European criteria for what mattered in civilizations. In conclusion, Uris suggested that the Baseline Essays "must be improved in their next revision and a clear district-wide implementation process must be designed." Caught between political struggles and 
poor scholarship with no strong administrative leadership, the writer warned, the concept of multicultural curriculum was in jeopardy in Portland. ${ }^{18}$

Criticism of Portland's African-American Baseline Essays coincided with and largely caused an intensified debate over Afrocentrism and the larger issue of multicultural education after 1990. A late-November 1990 article in the Congressional Quarterly by Robert K. Landers revealed that many scholars, including William $\mathrm{H}$. McNeill, a University of Chicago historian, viewed the Afrocentrist approach as going "well beyond the truth, not serious scholarship." The Afrocentric black nationalists, maintained Mc Neill, "are not historians. They are agitators." He attributed the growing influence of the Afrocentric perspective in the public schools to the seemingly hopeless condition of so many black youth in urban America. "This spirit of sectarianism seems to me potentially extremely dangerous," offered $\mathrm{McNeill}$. He and others advocated and helped create a dispassionate, scholarly approach. "What is needed," suggested McNeill, "is a common human past. [T] here is such a thing." 19

"I think at the root of the Afrocentric curriculum is a great despair at the plight of a large part of the African-American population," proclaimed Gary B. Nash, a professor of history at the University of California, Los Angeles. Nash advocated and helped create a "warts-and all," scholarly approach to the multicultural education effort in California. The call for an Afrocentric curriculum, he maintained, has "almost everything to do with the very difficult circumstances of a large portion of black children in the United States today." The people who are "pushing it," observed Nash, indicate that the problem they are trying to cure is low self-esteem in African-American children and the low performance levels that accompany it. That an Afrocentric version of history, or indeed any version, could attain that worthy 
purpose, Professor Nash suggested, is far from evident. "I surely wish history had the power to do all that the Afrocentrists claim it can do," he continued, "but it can't." History, Nash offered, does have "some potential for getting people to think about their world and operate in it actively as decision-makers and political participants," but "I do not believe that history can overcome problems of poverty and homelessness,[or of] drugs and violence and teenage pregnancy." ${ }^{20}$

John H. Bracey, professor of Afro-American Studies at the University of Massachusetts, Amherst, agreed. At the root of the Afrocentrist movement's current popularity, argued Bracey, is the belief that "because nothing else works, maybe, in order to counteract a mythology that says that blacks are of no value [a solution] is to give them a mythology that says black are of supreme value ... With the almost complete collapse of the urban school systems," he professed, "teachers are looking around for something that will get the students to stay in school and stay off drugs and get interested in some kind of scholarship." And some of those teachers, he continued, have come to think "that maybe looking at things from an Afrocentric point of view will be that mechanism."21

The heated controversy over Afrocentrism evoked a storm of criticism and discussion about larger issues related to the multicultural curriculum and American identity. In 1990, Diane Ravitch, professor of history and education at Teachers College, Columbia University, conceded that the issue of multicultural education had precipitated major controversy among educators and the public. Ravitch outlined two approaches to multicultural education, pluralist and particularist. Pluralists, she argued, promoted a broad interpretation of the "common American culture" and sought "due recognition" for the ways by which the nation's diverse racial, ethnic, and cultural groups had transformed the national culture. In contrast, the 
particularistic version of multiculturalism, under which Afrocentrism fell, denied that a common culture existed, and was not interested in extending or revising American culture. Such critics, suggested Ravitch, rejected any accommodation among groups or any interactions that blurred the distinct lines between them. She charged that particularists espoused a history that reduced everyone to either descendants of victims or oppressors, thereby fanning ancient hatreds in each new generation. ${ }^{22}$

This approach, Ravitch insisted, teaches children that their identity is determined by their "cultural genes." It stresses that something in their "race memory" or their "cultural DNA" defines who they are and what they may achieve. It professes to pupils, she continued, that the culture in which they live is not their own, that American culture is "Eurocentric," and therefore hostile to anyone whose ancestors are not European. The most "invidious" implication of the particularist approach, offered Ravitch, is that racial and ethnic minorities are not and should not try to be part of American culture, and implies that the larger American culture belongs only to those who are white and European. Moreover, she continued, it suggests that those who are neither white nor European are alienated from American culture by virtue of their race or ethnicity, and that the only culture the children belong to or "can ever belong to" is the culture of their ancestors, even if their families have lived in this country for generations. ${ }^{23}$

Critics of this approach to multiculturalism, she observed, are called "racist." "Particularism has its intellectual roots in the ideology of ethnic separatism and the black nationalist movement. In the particularist analysis, the nation has five cultures, she continued: African American, Asian American, European American, Latino/Hispanic, and Native American. The huge cultural, historical, religious, and 
linguistic differences within these categories are ignored, observed Ravitch, as is the considerable inter-marriage among these groups, as are the linkages (like gender, class, etc.) that cut across these five groups. No serious scholar, she pointed out, would claim that all Europeans and white Americans are part of the same culture, or that people of African descent, for instance, are of the same original culture. "Any categorization this broad is essentially meaningless and useless." 24

Accordingly, Ravitch was frustrated by her part in the effort to advance the multicultural curriculum in the California school system in the late-1980s. Despite the fact that the newly-created textbooks contained "more black history and better black history and more empathetic black history than any textbook on the market," maintained Ravitch, "there were people out on the streets chanting that their children were going to be victims of textbook genocide." Hearings before the State Board of Education showed what happens when ethnicity is unleashed at the expense of scholarship. "One group after another," the professor recalled, “insisted that its forebears had suffered more than anyone else in history," and that these schoolbooks had not gone far enough in celebrating their particular cultures or viewpoints. The persistent theme tying the hearings together was that critics did not want anything taught if it offended members of their group. The only villains in the history for the self-esteem movement, she observed, "were white males, who thus far have no spokesmen." These critics/activists, observed Ravitch, insisted that whatever was taught must have a positive effect on the self-esteem or pride of their group. "Once ethnic pride and self-esteem become the criterion for teaching history," Ravitch pointed out, certain things cannot be taught. "The real issue on campus and in the classroom," she maintained, "is not whether there will be multiculturalism, but what kind there [will] be."25 
Correspondingly, many historians and other academics criticized, through a manifesto, the New York task force's report, "a curriculum of inclusion" (July 1989), which emerged from the Empire State's lengthy effort to revise its curriculum and possessed strong Afrocentrist undertones and the consulting efforts of task member Leonard Jeffries. This manifesto, signed by over twenty-five well-known scholars, including psychologist Kenneth B. Clark, C.Vann Woodward, and Frances FitzGerald, indicated that its authors were "gravely concerned" over the "curriculum of inclusion['s]" "overheated rhetoric, overly simplistic analysis, and apparent disdain for U.S. institutions and the Western democratic tradition ... We condemn the reduction of history to ethnic cheerleading on the demand of pressure groups," and "steadfastly oppose the politicization of history, no matter how worthy the motive." Furthermore, the debate over the New York history curriculum produced thoughtful reactions from the state's history teachers. History, one wrote, "should not be a vehicle for pleasing or appeasing any social group, nor should teachers act as public-relations counselors for a cause. Writing history requires a critical analysis of a topic and not a laudatory exposition of its exploits." The Department of History at the State University of New York College at Brockport summed the question up in a circular letter to departments of history throughout the state: "We insist that the curriculum not be used as an instrument that is primarily designed to redress past injustices, however real. It is, rather, a tool with which to pursue the truths about our common past."26

In his 1991 book The Disuniting of America: Reflections on a Multicultural Society, historian Arthur Schlesinger, Jr. pointed out that the academic credentials of those leading the charge for Afrocentric education were in fields other than black studies and history. They and the teachers and educators who were the "foot 
soldiers," saw it as salvation for hundreds of thousands of black children who are doing poorly in the nation's public schools. Schlesinger acknowledged the importance of teaching the history of blacks, Africans, Asians, Hispanics and women. Yet "the whole notion that history should be taught as a means to improve self-esteem degrades history," he insisted. History should not be reduced to "filiopietistic commemoration," proclaimed Schlesinger. Accounts of Africans needed to acknowledge the "tyrannous authority they exercised, the ferocity of their wars, the tribal massacres, the squalid lot of the common people, the captives sold into slavery, the complicity with the Atlantic slave trade, the persistence of slavery in Africa after it was abolished in the West." ${ }^{27}$

The deeper reason for the Afrocentric campaign, professed Schlesinger, "lies in the theory that the purpose of history in the schools is essentially therapeutic: to build a sense of self-worth among minority children." No scientific study, he argued, showed any correlation between ethnic-studies programs and the self-esteem of ethnic groups. Eurocentrism, observed Schlesinger, by supposedly denying nonwhite pupils any past in which they can take pride, is held to be the cause of poor academic performance. Race consciousness and group pride are supposed to strengthen, the CUNY historian pointed out, a sense of identity and self-respect among non-white students. But American Afrocentrism is really a case of what the English historian Eric Hobsbawm called "the invention of tradition." Moreover, Schlesinger suggested why such an approach had appeal. The concern by many Americans surrounding the state of American education, especially in the cities, and the corresponding budgetary challenges led to a search for inexpensive remedies, particularly those which do not require much money and increased taxes. 
Curriculum revision costs little, appeases militant non-white minorities, and relieves guilt feelings among the white majority. ${ }^{28}$

When asked "Where is America headed?" historian Daniel J. Boorstin declared that the menace to the nation consisted of "the emphasis on what separates us rather than on what brings us together-the separations of race, of religious dogma, of religious practice, of origins of language." The idea of community permeated the whole of Boorstin's interview with journalist Tad Szulc. An unprecedented form of community-building, he insisted, was an essential part of "American Humanism," our nation's greatest achievement. This humanism was built upon "several happy accidents," he observed, starting with the arrival of people to a relatively unoccupied continent who were able to make a new life together, transcending the boundaries of European religion, race, and tradition. Like Crevecoeur, de Tocqueville and other exponents of "melting pot theory," Boorstin observed that in the face of these great challenges, "they established a new tradition that welcomed the stranger." 29

Boorstin confessed his concern over the "emphasis on power rather than on a sense of community." He perceived that separate groups were concerned about their power, and argued that the notion of a "hyphenated American is un-American. I believe there are only Americans." Boorstin indicated that there had been too much emphasis "recently on the diversity of our peoples," and suggested that it was time to re-affirm the fact that what has built our country is community and that community is not dependent on government. Communty, the historian instructed, is dependent on the willingness of people to build together. ${ }^{30}$

While this conflict generated a great deal of media coverage, the Africanization campaign had not captured the imagination of most American blacks. A Washington Post ABC poll in 1990 showed that 66 percent of its black 
respondents favored the use of the term "black" over "African-American." A 1991 survey by the Joint Center for Political and Economic Studies, a research organization specializing in African-American issues, found that 72 percent of its respondents of color preferred the term "black" to indicate their ethnicity. Perhaps this is because, as the historian Nathan Higgins has suggested, "An Afro-American and the grandson of a Polish immigrant will be able to take more for granted between themselves than the former could with a Nigerian or the latter with a Warsaw worker." As even Asante concedes, when black Americans visit Africa, Africans perceive them as plain Americans and hardly as African at all. ${ }^{31}$

Columnist William Raspberry of The Washington Post expanded further on this theme. "Anyone who knows anything about Africa, argued Raspberry, "knows that there is no single 'African, culture from which black Americans are descended ... While some Africans were establishing a University at Timbuktu, others were engaged in slavery or tribal warfare or cannibalism." Some Africans, he observed, were monotheists, while others were animists. "As with their European counterparts, some were promoting brilliant philosophies, while others were savages." As for the Afrocentric curriculum, Raspberry adds, it is a "questionable assumption that black children, with only the vaguest notions of their African ancestry, can be inculcated with African culture more easily than the American culture to which they are daily exposed." 32

While acknowledging that "historical black institutions" had a responsibility to teach young people about their particular history and culture, Howard University president, Franklyn Jenifer of Howard University, had noted that "[o]ne has to be very careful when one is talking about public schools ... Public schools by their definition are schools that are open to all people, and should be cognizant of the 
needs of all of the people ... There should be no creation of nonexistent history." Similarly, Henry Louis Gates Jr., chair of the Afro-American Studies at Harvard University, in articles entitled "Beware of the New Pharaohs" (1991), and "Black Demagogues and Pseudo-scholars" (1992), assailed the bogus conspiracy and other theories, "the invidious scapegoating" of ethnic groups, espoused by Afrocentrists. ${ }^{33}$

This separatist brand of multiculturalism fit into the larger "politically correct" stream which oozed into higher educaion in the early-1990s. Such an influence facilitated a "victim/oppressor" paradigm, which insisted that all that was European or derived from a white (European) male has to be suspect, while the utterances of the oppressed were to deserve instant credence. Conspiracy theory, overtly mechanistic analysis, and ethnic scapegoating, which also caters to Americans' great fondness for simplicity in the face of fear and impotence, were among the tools Afrocentrists and their followers appeared to use to vent their frustration and ineffectiveness. Such modes of victimization had been addressed by scholars such as Shelby Steele. Advancement of black Americans, Steele suggested, "will derive from a renewed focus on developing ourselves as individuals and embracing opportunity." 34

Attempting to identify why black Americans clung to an "adversarial, victimfocused identity," he suggested that "we carry an inferiority anxiety, an unconscious fear that the notion that we are inferior may be true-that makes the seizing of opportunity more risky for us, since setbacks and failures may seem to confirm our worst fears." Victimization, he argued, "has been our primary source of power in society-the basis of our demands for redress." The paradoxical result of relying on such a source of power, Steele offered, was that it rewarded black Americans for "continuing to see ourselves as victims of a racist society and implies that opportunity 
itself is something to be given instead of taken." Such a destructive dynamic not only fans old resentments, but when one's power is derived through powerlessness, personal power, responsibility, and initiative, the primary means required to rid oneself of a victim-oriented paradigm, are eroded..$^{35}$ 


\section{CONCLUSION}

Pluralist values associated with the "melting pot" permeated criticism of the Portland Public Schools African-American Baseline Essays. Proponents of such views believed that American civilization rested upon the subordination of ethnicity and tribal hostilities to an overarching culture that rewarded individual achievement on the basis of character. Afrocentrism, in contrast, evolved from the "particularist" traditions of black nationalism, which responded to a sense of powerlessness, and despair within African-American communitities and resentment over their exclusion from mainstream culture. ${ }^{1}$

Like the curricula conflicts that raged in California and New York school systems, the Portland controversy pitted advocates of "Afrocentrism" against the perceived enemy of "Eurocentrism," reducing complex histories to misleadingly simple terminology. Ironically, by claiming credit for western civilization, Afrocentrists unwittingly elevated European culture above all else, and ignored the unique contributions of African-Americans and Africans. It stands to reason that an unvarnished historical account would restore black Americans and Africans to "their rightful place" more than fantasy of a "glorious past." Such methodology also introduced the danger of violating fundamental historical standards and trivializing the meaning of history, thereby alienating teachers who took their responsibilities seriously. Moreover, Afrocentrism's promise of elevated self-esteem illustrated the unrelenting search for quick-fixes, even with enormously complicated problems like those associated with race relations and inner-cities. ${ }^{2}$

This emotionally-charged conflict occurred during a period when the demise of the ideological conflicts of the Cold War was releasing long-standing ethnic conflicts. Ethnic and racial tensions had figured into the fragmentation of nations 
such as the Soviet Union, Yugoslavia and South Africa, and threatened instability in the United Kingdom, France, Belgium, Spain and Canada. "The virus of tribalism," asserted the Economist in 1991, "risks becoming the Aids of international politics-lying dormant for years, then flaring up to destroy countries."

Coinciding with and responding to ethnic strife abroad and inner-city decay, social critics such as Professor Allan Bloom and essayist Robert Hughes were lamenting what they saw as the closing of the American mind and the fraying of the United States. Some multiculturalists propounded "cultural separatism within the larger whole of America," argued Hughes. "When a nation's diversity breaks into factions," he charged, "demagogues rush in, false issues and choices cloud debate, and everybody has a grievance." Arthur Schlesinger, Jr.'s The Disuniting of America offered some observations on the topics of the common past inherent in the American identity. Like other observers, Schlesinger pointed out that public schools had long been "the great instrument of assimilation and the great means of forming an American identity ... The debate about the curriculum is a debate about what it means to be an American," he concluded. Historian Daniel Boorstin, in an interview entitled "The Greatest Danger We Face" (1993), argued that the threat to America was in the emphasis on what separates us rather than on what unifies us. While Afrocentrists and other cultural separatists used history as a weapon, more balanced historians and educators called for a scholarly approach, providing a means to understand ourselves and others. "What is needed," suggested William H. Mc Neill, a historian at the University of Chicago, " is a common past." "Feel- good history," observed author Gore Vidal, is a betrayal of a noble prof ession. ${ }^{4}$

Despite the protracted excitement which characterized the whole of this debate, it is significant to recall that at its apex, in the late-1980s and early-1990s, the 
Africanization campaign had not captured the imagination of most black Americans.

While African-Americans had not been melded into the mainstream to the degree that other ethnic groups had, the long chronicle of race-relations and the many and varied contributions blacks have made to the larger culture, point to an uninterrupted movement toward this end. Overwhelmingly, blacks have historically seen themselves as Americans first, oftentimes using this, and that which it implies, as the primary means for redress. ${ }^{5}$

While Af rocentric education remained an important part of the Baseline controversy, questionable techniques by District administrators, consultants, and community activists aggravated the situation. Infused with a pioneer spirit, a desire to "do the right thing," and community pressure for a more inclusive public school system and curriculum, Portland became the pilot city for public school reform. Yet the militancy of community groups such as the Black United Front, and its strongarm, DMAC, gave the organizations excessive influence in the Portland multicultural curriculum effort. Although the BUF enjoyed widespread support for its strong leadership, the Front's liberation ideology and Afrocentric focus did not necessarily represent the black community's diverse desires and perspectives. ${ }^{6}$

The group exploited its position as outspoken critic of the status-quo to further its own agenda. Portland curriculum consultants were of ten hand-picked by BUF. These included, among many others, Hunter Adams, a science baseline author whose credentials were grotesquely stretched. BUF leaders such as Ron Herndon and Joyce Harris lacked a fundamental understanding of school district managment and tended to engage in combative techniques designed to advance a highly politicized agenda. Moreover, as the Baseline Essays' formal release 
approached, the Front illustrated overt signs of splintering between its members over how to proceed with the endeavor, exacerbating the conflict further. ${ }^{7}$

Poor methods also characterized Prime Consultant Hilliard's tenure. That Hilliard could have celebrated the completion of the African-American Baseline Essays in the face of uniform resistance, indicates his unrealistic evaluation. Similarly, his continual waffling on issues such as defining "baseline" and the means of promoting their quality calls into question his effectiveness as a consultant. In a climate of extreme mutual distrust between the District and the black community, Hilliard found himself unable to resolve the tensions that threatened to destroy the Portland experiment. Perhaps Hilliard saw his role as one designed to keep the two disparate parties talking. Yet the prime consultant's twice-a-year visits and substance-sparse reports did little to facilitate any kind of compromise. Hilliard's unwavering reticence throughout this period and his unwitting association with the militant rhetoric and influence of the Front, placed him at odds with many officials and teachers. Moreover, the District's long-standing conf rontations with the BUF further reduced possibilities of reconciliation. By the time the Front disappeared as a force at the end of 1987 and Asa Hilliard's consultantship had ended, the damage had been done. ${ }^{8}$

For the District's part, its good faith effort to rectify the curriculum and mend relations with Portland's African-Americans left many community members skeptical, given the long history of failing to involve black parents and leaders as equal decision-makers. In such an atmosphere of mistrust, professional reservations from teachers and District staff could be interpreted by the city's black community as reluctance to commit the educational establishment to multiculttural education. Yet the District also set unrealistic timeframes and mismanaged teacher training. In 
addition, Portland educators failed to take responsibility for effectively monitoring the process by which the essays were created. In the end, the essays languished on teachers' shelves, al though some teachers took it upon themselves to integrate multicultural material into their curriculum. Moreover, the campaign for multicultural education resulted in a greater inclusion of African-Americans in the decision-making processes of the Portland School District. ${ }^{9}$

As public education has historically been a forum upon which unresolved conflicts have played themselves out, Portland Public Schools made a vital and potentially useful contribution to the national dialogue. For its part, the District's African-American Baseline Essays and the heated response which followed had a significant impact on multicultural education and the larger issues of ethnic and race relations and American identity. What constitutes multicultural education is an issue upon which reasonable, intelligent and caring individuals differ, and of ten quite passionately. The Portland story illustrates that such ideas should be debated within an arena of pluralism in which a richer common culture is sought. While Americans have witnessed painstaking efforts to expand the understanding of the varied tapestry of their culture over the past twenty-five years, the debate over Afrocentrism has crystallized the issues. This heated controversy has provided an opportunity to examine a variety of national problems extending from race relations to public education to American identity. The controversy over the Portland Public Schools' African-American Baseline Essays is simply an additional chapter to the nation's historic struggle to seek a coherent identity among an increasingly diverse community. 


\title{
ABBREVIATIONS
}

\author{
AIM American Indian Movement \\ APA American Protective Association \\ ATP Administrative Transfer Program \\ BSU Black Student Union, which evolved from the Negro Students \\ Association \\ BUF Black United Front \\ CDP Comprehensive Desegregation Plan \\ COALITION Community Coalition for School Integration \\ CORE Committee on Racial Equality \\ CRI Committee on Racial Imbalance \\ CUNY City University of New York \\ DMAC Desegregation Monitoring and Advisory Committee \\ DOI Director of Instruction \\ ECEC Early Childhood Education Centers
}


FRONT Black United Front

ME/MC Multiethnic/Multicultural effort and/or materials

METF Multicultural/Multiethnic Education Task Force

NAACP National Association for the Advancement of Colored People

NNC National Negro Congress

SNCC Student National Coordinating Committee, which evolved from Student Non-Violent Coordinating Committee

UNIA Universal Negro Improvement Association 
NOTES

INTRODUCTION

I “Curriculum Seeks to Lift Blacks' Self-Image," The New York Times, 8 March 1989, I, PP. 1, 24.

${ }^{2}$ Diane Ravitch, "Multiculturalism, E Pluribus Plures," The American Scholar, 16 (Summer 1990), PP. 337-338.

${ }^{3}$ Gunnar Myrdal, An American Dilemma (New York: Harper and Row Publishers, Incorporated, 1944), Chapter 1.

${ }^{4}$ Ravitch, "Multiculturalism, E Pluribus Plures," The American Scholar, p. 338.

${ }^{5}$ Robert K. Landers, "Conflict Over Multicultural Education," Congressional Quarterly's Editorial Research Reports, 1, no. 44 (30 November 1990), PP. 682-694.

${ }^{6}$ Lorraine V. Forte, "Schools embrace multicultural trend," Catalyst Voices of Chicago School

Reform, 2, no. 4 (December 1990), p. 2.

\section{CHAPTER 1}

${ }^{1}$ Gary B. Nash, Red, White, and Black, (Los Angeles: Prentice Hall, 1974), PP. 46-120; Herbert Aptheker, The Colonial Era: A History of the American People, (New York: International Publishers, 1966), p. 18.

${ }^{2}$ Leonard Dinnerstein and David M. Reimers, Ethnic Americans: Second Edition, (New York: Harper and Row, Publishers, Inc., 1982), PP. 10-12; Bureau of the Census, Historical Statistics of the United States, Colonial Times to 1970, (Washington, D.C.: U.S. Department of Commerce, 1976), p. 12.

${ }^{3}$ Dinnerstein and Reimers, Ethnic Americans, PP. 32-34, 70-86.

${ }^{4}$ Hector St. John De Crevecoeur, Letters From An American Farmer, (New York: E.P. Dutton and Co. Inc., 1912), PP. 41-44).

${ }^{5}$ J.C. Fitzpatrick, ed., George Washington's Writings, (Washington, D.C.: U.S. Govt. Print. Off., 1938), PP. xxvii, 252, xxiv, 23.

${ }^{6}$ Joel Porte, ed., Emerson in His Journals, (Cambridge, Belknap Press of Harvard University Press, 1982), p. 347.

${ }^{7} 7$ Roger Boesche, ed., Selected Letters on Politics and Society, (Berkeley: University of California Press, 1985), p. 38.

${ }^{8}$ Myrdal, An American Dilemma, Chapter 1.

${ }^{9}$ Winthrop D. Jordan, White Over Black: American Attitudes Toward the Negro, 1510-1812,

(Chapel Hill: University of North Carolina Press, 1968), 512-538; Dinnerstein and Reimers, Ethnic Americans, p. 2; Arthur Schlesinger Jr., The Disuniting of America: Reflections on a Multicultural Society, (New York: W.W. Norton and Company, 1991), p. 29. 
${ }^{10}$ George E. Pozzetta, ed., American Immigration and Ethnicity: Nativism, Discrimination, and Images of Immigrants, (New York: Garland Publishing, Inc., 1991), p. 31 1; David H. Bennett, The Party of Fear: From Nativist Movements to the New Right in American History, (Chapel Hill: The University of North Carolina Press, 1988), p. 171; Dinnerstein and Reimers, Ethnic Americans, p. 57.

${ }^{11}$ Dinnerstein and Reimers, Ethnic Americans, PP. 50-52, 63, 73; Ronald Takaki, A Different Mirror: A History of Multicultural America, (Boston: Little, Brown, and Company, 1993), PP. $126-131,138,200,402$.

${ }^{12}$ Bennett, The Party of Fear, PP. 165, 181, 198-199, 208-214; ; Dinnerstein and Reimers, Ethnic Americans, PP. 59-60.

${ }^{13}$ Bennett, The Party of Fear, PP. 268-271, 283; Ronald Takaki, A Different Mirror: A History of Multicultural America, (Boston: Little, Brown, and Company, 1993), PP. 304-310; Dinnerstein and Reimers, Ethnic Americans, p. 60.

${ }^{14}$ Takaki, A Different Mirror, PP. 8, 304-310, 330, 382-383, 401-402; Bennett, PP. 200, 205-206, $246,264-265$

${ }^{15}$ August Meier and Elliott Rudwick, From Plantation to Ghetto: Third Edition, (New York: Hill and Wang, 1966), PP. 227, 233, 253-254, 266.

${ }^{16}$ Ibid., PP. 266-268.

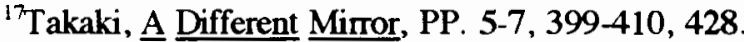

${ }^{18}$ Frederick Douglass's quotation is from his article "African Civilization Society," Douglass'

Monthly, February 1859, reprinted in Philip S. Foner, ed., Life and Writings of Frederick Douglass, (New York: International Publishers, 1950), vol. II, p. 443; Cyril E. Griffith, The African Dream: Martin $\underline{R}$. Delany and the Emergence of Pan-African Thought, (University Park: Penn State University Press, 1975), PP. 14.

${ }^{19}$ Meier and Rudwick, From Plantation to Ghetto, PP. 120, 246-251, 253, 286, 355.

${ }^{20}$ Ibid.; Meyer Weinberg, ed., W.E.B. Du Bois: A Reader, (New York: Garland Publishing, Inc., 1970), p. 373; "Rethinking Black History," Harvand Educational Review, August 1971, p. 310; Amy Jacques-Garvey, ed., Philosophy and Opinions of Marcus Garvey, (New York: Atheneum, 1969), p. 1.

${ }^{21}$ Maulana Karenga, Introduction to $\underline{\text { Black }} \underline{\text { Studies, }}$ (Los Angeles: University of Sankore Press, 1993), PP. 247-249.

${ }^{22}$ Ibid., 169; Stokely Carmichael and Charles V. Hamilton, Black Power: The Politics of Liberation in America, (New York: Alfred A. Knopf, Inc., 1967), p. 54; Rhoda Lois Blumberg, Civil Rights: The 1960s Freedom Struggle, (Boston: Twayne Publishers, 1991), PP. 135-137.

${ }^{23}$ Blumberg, Civil Rights, PP. 141-142, 200; David A. Horowitz, Peter N. Carroll, and David D.

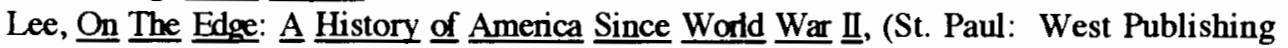
Company, 1989), PP. 158, 202-203.

${ }^{24}$ Horowitz, Carroll, and Lee, On The Edge, p. 204.

${ }^{25}$ Joan Didion, The White Album, (New York: Simon and Schuster, 1979), p. 30; Horowitz, Carroll, and Lee, On The Edge, PP. 202-204; Blumberg, Civil Rights, PP. 144-145.

${ }^{26}$ Carmichael and Hamilton, Black Power, p. 38; Blumberg, Civil Rights, PP. 146-147; Molefi Kete Asante, Afrocentricity, (Trenton, Africa World Press, 1992), PP. 123-124; Karenga, Intro. to Black Studies, p. 17; Horowitz, Carroll, and Lee, On The Edge, p. 206; Schlesinger, Disuniting of America, p. 85.

${ }^{27}$ Schlesinger, Disuniting of America, PP. 85-86, 147; Blumberg, Civil Rights, 147-148.

${ }^{28}$ Herbert Hill and James E. Jones, Jr., Race in America: The Struggle For Equality, (Madison: University of Wisconsin Press, 1993), PP. 53-54; Carmichael and Hamilton, Black Power, PP. 3738.

${ }^{29}$ Karenga, Intro. to Black Studies, PP. 3,7-8, 26. 
${ }^{30}$ Ibid., PP. 34-35; Asante, Afrocentricity, p. vii; Alex Boyd, and Catherine J. Lenix-Hooker, "Afrocentrism: Hype or history?," Libraray Journal, 117, no. 1 (November 1, 1992), p. 46; Forte,"Schools embrace multicultural trend," Catalyst Voices of Chicago School Reform, p. 2; Jerry Adler, "African Dreams," Newsweek, 23 September 1991, p. 46.

${ }^{31}$ Asante, Afrocentricity, PP. 2, 20, 38, 43, 67; Adler, "African Dreams," Newsweek, 23 September 1991, p. 42.

${ }^{32}$ Debra Viadero,"Battle Over Multicultural Education Rises in Intensity," Education Week, 10, no. 13 (28 November 1990), PP. 1, 11-13; John Henrik Clarke, Social Studies African-American Baseline Essay, (Multicultural/Multiethnic Education Office, Portland Public Schools' Archives, 1987), PP. 4, 8-11, 56, 60; Boyd, and Lenix-Hooker, “Afrocentrism: Hype or History?," Library Journal, PP. 46-47.

${ }^{334}$ "Suspicion on Racism Rift," New York Newsday, 19 August 1991, PP. 3, 25-29; "Putting Africa on the Map, 'racist' history assailed," The Washington Times, 13 November 1990, PP. 1, 10-11; Lance Morrow, "The Provocative Professor," Time, 26 August 1991, PP. 19-20. The militant rhetoric of scholar/actists such as Jeffries and Clarke, along with their grandiose claims about African and African-American contributions, seems to reflect a deep resentment by black Americans for exclusion from mainstream Ameirica. Furthermore, the anti-Semitic underpinnings might be explained by the perception by African-Americans that Jews have received a disproportionate quantity of recognition for their long histoy of persecution, while enjoying uneven amounts of power and success in most realms of American society. See Paul Berman, ed., Blacks and Jews: Alliances and Arguments, (New York: Dell Publishing, 1994); Cornell West, Race Matters, (Boston: Beacon Press, 1993); Shelby Steele, The Content of Our Character, (New York: St. Martin's Press, 1990); Henry Louis Gates, "Beware of the New Pharaohs," Newsweek, 23 September 1991, p. 47, and "Black Demagogues and Pseudo-Scholars," New York Times, 20 July 1992, p. 10.

344"Putting Africa on the Map, 'racist' history assailed," The Washington Times, 13 November 1990 , PP. 1, 10-11.

${ }^{35}$ Horowitz, Carroll, Lee, On The Edge, PP. 208-210.

${ }^{36}$ Ibid., p. 210.

${ }^{37}$ Emmett H. Buell, School Desegregation and Defended Neighborhoods, (Lexington: Lexington Books, 1982), PP. 6-7, 11, 24,33; Michael Novak, The Rise of the Unmeltable Ethnics: Politics and Culture in the Seventies, (New York: Macmillan, 1972), p. 14; Dale S. McLemore, Racial and Ethnic Relations in America, (Boston: Allyn and Bacon, 1980), p. 329; Ravitch,

"Multiculturalism: E Pluribus Plures," The American Scholar, PP. 338-340.

${ }^{38}$ Forte, "Schools embrace multicultural trend,"Catalyst Voices of Chicago, PP. 1-2.

\section{CHAPTER 2}

'Office of the Superintendent, Chronology and History: Desegregation/Integration, Portland Public Schools (1960-1982), Portland Public Schools' Archives, September 1981, p. 1. Lincoln was the name of the indicated high school.

${ }^{2}$ Ibid., PP. 1-2; Ray C. Rist, The Invisible Children: School Inteegration in American Society, (Cambridge: Harvard University Press, 1978), PP. 25-27; L. G. Holmes, ed., The Real Estate

Handbook, ( Englewood Cliffs, New Jersey: Prentice-Hall, Inc., 1948), p. 420.

${ }^{3}$ Office of the Superintendent, Chronology and History, p 2.

${ }^{4}$ Ibid., PP. 2-3.

${ }^{5}$ Ibid., p. 3.

${ }^{6}$ Ibid , PP. 5, 8, 19-20. Rev. Wright cited the Board's 1961 pamphlet, "Principles of Education." 
${ }^{7}$ Office of the Superintendent, Chronology and History, PP. 37-38, 195; Committee on Race and Education, Herbert M. Schwab, Chairman, Race and Equal Educational Opportunity in Portland's Public Schools, A Report to the Board of Education, Multnomah School District, No. 1, 29 October 1964, PP. 194-196, Portland Public Schools' Archives.

${ }^{8}$ Office of the Superintendent, Chronology and History, PP. 19, 37, 105.

${ }^{9}$ Ibid., PP. 21, 113-115.

${ }^{10}$ Ibid., PP. 113, 117-118, 139.

${ }^{11}$ Ibid., p. 113; Community Coalition For School Integration (the Coalition), Equity For the

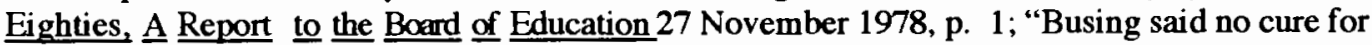
white escape," Oregonian, 15 December 1977, p. 2; Memorandum from Superintendent Robert W. Blanchard to the Board of Education, 1 November 1979, PP. 6, 28, Portland Public Schools' Archives.

${ }^{12}$ Coalition, Equity For the Eighties, chapter I, PP. 1-3;

${ }^{13}$ Ibid., PP. 1-4; "Black children said 'isolated' despite busing," Oregonian, 8 December 1977, B, p. 3.

${ }^{14}$ Coalition, Equity For the Eighties, PP. 14-15.

${ }^{15}$ Ibid., PP. 5-6; "Integration plans questioned," Oregonian, 6 October 1978, B, p. 3; Coaliton, Equity For The Eighties, PP. 9-14, 27-34.

${ }^{16}$ Coalition, Equity For The Eighties, PP. 17-18.

${ }^{17}$ Office of the Superintendent, Superintendent's Response to the Report and Recommendations of the Community Coalition For School Integration, 11 December 1978, PP. 1-3, 12-13, 21, , Portland Public Schools' Archives.

${ }^{18}$ Tbid., PP. 24-28, 31; Memorandum from Robert W. Blanchard to the Board of Education, 5 January 1979, 2, 4-5; Coaliton, Equity For The Eighties, p. 3.

${ }^{19}$ Superintendent's Response to the Report and Recommendation of the Community Coaliton For School Integration, 11 December 1978, PP. 13-15, Portland Public Schools' Archives.

20 "Gains of Black United Front win respect," Oregonian, 21 July 1983, B, p. 4.

${ }^{21}$ Memorandum from Superintendent Blanchard to Verne A. Duncan, Superintendent of Public Instruction, 1 November 1979, PP. 5, 18, Portland Public Schools' Archives; "Portland schools quietly moving to resegregation," Oregonian, 14 April $1985, \mathrm{C}, \mathrm{p} .2$;

22 "Portland schools...," Oregonian, 14 April 1985, C, p. 2; Memorandum From Blanchard to Duncan, 1 November 1979, PP. 3,5-6; Memorandum from Blanchard to Board, 5 January 1979. PP. 25-29, Portland Public Schools' Archives.

23 "Portland schools...," Oregonian, 14 April 1985, C, p. 2; Portland Public Schools, Comprehensive Desegregation Plan, 14 April 1980, Portland Public Schools' Archives.

24 "Dissenters fault board: Blanchard fired for 'retreating." Oregonian, 29 June 1980, C, PP. 1-2.

${ }^{25}$ Superintendent's Annual Report to the Board of Education on Racial Balance, 29 September 1980, PP. 28-29, Portland Public Schools' Archives.

${ }^{26}$ Ibid., 25; Report of Consultation by Asa G. Hilliard, Chief Desegregation Consultant, 14 June 1984, p. 1, Portland Public Schools' Archives.

${ }^{27}$ Memorandum from Assistant Superintendents James Fenwick and Edwin Schneider to Asa Hilliard, 3 June 1982, p. 1, Portland Public Schools' Archives; Superintendent's Report, 29 September 1980, PP. 22, 25.

${ }^{28}$ Elizabeth MacGregor Geddes, "Desegregation/Integration--Policies and Practices: Portland Public Schools, Portland, Oregon, 1970," (Ph. D. dissertation, Brigham Young University, 1982), 451 453; Desegregation Monitoring Advisory Committee, Report to the Board of Education, 1980-1981, PP. $1,4-510,47-48$. 


\section{CHAPTER 3}

${ }^{1}$ Memorandum from Asa Hilliard to Associate Superintendent for Staff Development and Human Relations, 16 January 1981, PP. 8-9, Portland Public Schools' Archives; "Multicultural curriculum in the PPS," Portland Observer, 6 May 1982, p. 1.

2 "Multicultural curriculum...," Portland Observer, 6 May 1982, p. 1; Superintendent's Report, 29 September 1980 , p. 21.

3 "Protesters disrupt meeting," Oregonian, 30 March 1982, B, p. 1; "End school board disruptions," Oregonian, 14 April 1982, B, p. 6.

4 "Protesters disrupt meeting," Oregonian, B, p. 1.

5 "Gains of Black United Front win respect," Oregonian, 21 July 1983, B, p. 4.

6 "Multicultural curriculum...," Portland Observer, 6 May 1982, p. 2.

${ }^{7}$ Ibid.

8 Ibid., PP. 2-3.

${ }^{9}$ Ibid., p. 1; Memorandum, from Fenwick and Schneider to Hilliard, 3 June 1982, PP. 2-5, Portland Public Schools' Archives.

${ }^{10}$ Memorandum, 3 June 1982, PP. 2-5.

${ }^{11}$ Memorandum from Asa Hilliard to Ernest Hartzog, 7 June 1982, PP. 2-3, Portland Public Schools' Archives.

${ }^{12}$ Ibid., p. 3. Scope and Sequence were to be revised by the Curriculum Department and the local and national consultants.

${ }_{13}$ Ibid.

${ }^{14}$ Report of Visitation from Asa Hilliard to Ernest Hartzog, 12 November 1982, p. 1, Portland Public Schools' Archives.

15 Ibid., p. 2.

${ }^{16}$ Concept Paper from Darrell Millner to Portland Public Schools, 17 January 1983, PP.1-2,

Portland Public Schools' Archives.

17 Ibid., PP. 2-7.

${ }^{18}$ Ibid.

19 Ibid.

${ }^{20}$ Ibid., p. 7.

${ }^{21}$ Ibid., PP. 15-17.

22 Ibid.

23 Ibid., p. 18-19.

${ }^{24}$ Ibid.

${ }^{25}$ The insights expressed herein were derived from conversations in the early-1990s with individuals intimately involved with these processes who requested that their anonymity be honored.

26 "Be skeptical," Oregonian, 28 July 1983, B, p. 6; "Black studies program still raising questions," Oregonian, 24 April 1989, B, PP. 1, 8.

${ }^{27}$ Darrell Millner, et al, Comprehensive Staff Training for incorporating African-American curriculum materials into curriculum, 15 May 1984, p. 1.

${ }^{28}$ Ibid., p. 1; Anonymous sources acknowledged to the author that Adams was a janitor with a high school diploma.

${ }^{29}$ Ibid., PP. 1-2.

${ }^{30}$ Report of Consultation from Asa Hilliard to the Board of Education, 14 June 1984, p. 1, Portland Public Schools' Archives.

${ }^{31}$ Ibid., PP. 1-3.

${ }^{32}$ Ibid., PP. 4-5; Report of Visitation from Asa Hilliard to Ernest Hartzog, 8 January 1987, PP. 1,5, Portland Public Schools' Archives; Report of Consultation from Asa Hilliard to the Board, 14 June 1984, PP. 1-5; informal letter from Asa Hilliard to Superintendent Prophet, p. 1, Portland Public Schools' Archives. 
${ }^{33}$ Memorandum from Superintendent Matthew Prophet to the Board of Education, 21 June 1984, PP. 1-2, Portland Public Schools' Archives.

${ }^{34}$ Ibid.

${ }^{35}$ Ibid.

${ }^{36}$ Memorandum from Superintendent Prophet to Asa Hilliard, 25 June 1984, p. 2, Portland Public Schools' Archives; Memorandum from Asa Hilliard to Matthew Prophet, 2 July 1984, PP. 1-2, Portland Public Schools' Archives.

37 "Portland schools quietly...," Oregonian, 14 April 1985, C, p. 2; Memorandum from

Superintendent Prophet to the Board of Education, 30 July 1984, PP. 1-2, Portland Public Schools' Archives.

${ }^{38}$ Comprehensive Desegregation Plan, Progress Report from Superintendent Prophet to the Board of Education, January 1985, PP. i, ii, Portland Public Schools' Archives.

${ }^{39}$ Ibid., PP. 8-9.

${ }^{40}$ Memorandum from Asa Hilliard to Ernest Hartzog, 1 July 1985, PP. 1-2, Portland Public

Schools' Archives.

${ }^{41}$ Ibid.

${ }^{42}$ Cleveland Cluster Principals Packet on Multiethnic Education, Summer 1985, PP. 4-6, Portland Public Schools' Archives.

43 "Fighting Words," Oregonian, 8 March 1992, B, PP. 7, 10.

${ }^{44}$ Ibid.

${ }^{45}$ Ibid.

${ }^{46}$ Ibid

47 "Multicultural training program stirs doubts," Oregonian, 3 March 1986, C, p. 8.

${ }^{48}$ Research and Evaluation Department and Management Information Services, Portland Public Schools, A Statistical Portrait, 1986-1987, PP. 8-10, 12, 69-71, Portland Public Schools' Archives.

${ }^{49}$ Memorandum from Asa Hilliard to Ernest Hartzog, 8 January 1987, PP. 1, 5, Portland Public Schools' Archives.

${ }^{50}$ Report from DMAC to the Board of Education, Jume 1987, PP. 1-5, Portland Public Schoools' Archives. Some of the insights derived from conversations with individuals intimately involved with these processes, who requested that their anonymity be honored.

51 "Portland schools' curriculum criticized," Oregonian, 26 June 1987, D, p. 3. Herndon would retreat from directly intervening in the District's multicultural efforts. Along with Joyce Harris and others, he attempted to assemble programs within neighborhood churches to realize Afrocentric pursuits and the desire to help at-risk children. Lamenting Portland Public School's achievement gap between middle-class and black, Hispanic, Indian and poor white children as they entered the age of high technology, Ron Herndon had some suggestions. "The way to do it," offered Herndon, was to assemble the most talented teachers and administrators, from inside and outside the District, and ask them to share what works and how it can be replicated. See "Portland's schools divided into 2 systems, and one doesn't work," Oregonian, 24 April 1987, D, p. 13.

52 "Putting Africa at the Center," Newsweek, 23 September 1991, p. 46; Report of Visitation, from Asa Hilliard to Ernest Hartzog, p. 1, Portland Public Schools' Archives.

\section{CHAPTER 4}

${ }^{1}$ John Leo,"A fringe history of the world," U.S. News $\underline{\text { \& Word }}$ Report, 12 November 1990, p. 25

${ }^{2}$ Ibid.,p. 25-26.

${ }^{3}$ Ibid. 
4 "A return to segregationist history," Oregonian, 18 November 1990, B, p. 2.

${ }^{5}$ Ibid.

${ }^{6}$ Ibid.

${ }^{7}$ Ibid; "Temporarily fogged or fatally tinted?" Oregonian, 27 November 1990, B, p. 3.

8 "African teachings draw criticism," Oregonian, 18 November 1990, D, p. 1.

${ }^{9}$ Ibid., D, PP. $1,7$.

${ }^{10}$ Ibid., D, 7 .

"Ibid.

12 "Essays an insult," Oregonian, 5 December 1990, B, p. 15.

${ }^{13}$ Debra Viadero, "Battle Over Multicultural Education Rises in Intensity," Education Week, 10, no 13, 28 November 1990, PP. 1, 11-13; Social Studies African-American Baseline Essay, 28 June 1993, p. 52. Portland Public Schools' Archives.

14 "Baseline Essays add to mistakes of past," Oregonian, 16 October 1991, B, p. 14.

15 "Multicultural curriculum in the PPS," Portland Observer, 6 May 1982, PP. 1-2; Memorandum

from Asa Hilliard to Ernest Hartzog, 1 July 1985, p. 2, Portland Public Schools' Archives; "An invitation you should not refuse," Oregonian, 13 February 1992, B, 2.

16 "Fighting Words," Oregonian 8 March 1992, B, PP. 7, 10.

${ }^{17}$ Ibid.

${ }^{18}$ Ibid

${ }^{19}$ Landers, "Conflict Over Multicultural Education," Congressional Quarterly's Editorial Research Reports, 30 November 1990, p. 694.

${ }^{20}$ Ibid., p. 684.

${ }^{21}$ Ibid.

${ }^{22}$ Ravitch, Multiculturalism," American Scholar, Summer 1990, PP. 341-342.

${ }^{23}$ Ibid., 340-342.

${ }^{24}$ Ibid.

${ }^{25}$ Landers, "Conflict," Congressional Quarterly's Editorial Research Reports, 30 November 1990, PP. 683-689; Schlesinger, Disuniting of America, PP. 96-97.

26 "Where we stand," New York Times, 12 August 1990, p. 49; Schlesinger, Disuniting of America, PP. 98-99.

${ }^{27}$ Schlesinger, Disuniting of America, PP. 69-70, 75-93.

${ }^{28} \mathrm{Ibid}$

29 “The Greatest Danger We Face," Washington Post, 25 July 1993, P, PP. 4-6.

${ }^{30}$ Ibid.

${ }^{31}$ Schlesinger, Disuniting of America, p. 88.

${ }^{32}$ Ibid., p. 87.

${ }^{33}$ Ibid., p. 98; Henry Louis Gates, "Beware of the New Pharaohs," Newsweek, 23 September 1991, p. 47; "Black Demagogues and Pseudo-Scholars," New York Times, 20 July 1992, p. 10.

${ }^{34}$ "The opportunity society," Utne Reader, September/October 1991, PP. 55-56. For an analysis of these and related themes, Shelby Steele, The Content of Our Character, (New York: St. Martin's Press, 1990).

${ }^{35}$ Steele, The Content of Our Charcter.

\section{CONCLUSION}

${ }^{1}$ Schlesinger, Disuniting of America, PP. 9-43; "The Greatest Danger We Face," Washington Post, 25 July 1993, P, PP. 4-6; Ravitch, "Multiculturalism: E Pluribus Plures," American Scholar, PP. 
337-354; Landers, "Conflict Over Multicultural Education, Congressional Quarterly, PP. 682- 694; Asante, Afrocentricity, PP. 1-103.

${ }^{2}$ Landers, "Conflict...," Congressional Quarteriy, PP. 682-690; Ravitch, "Multiculturalism," PP. 337-354; "Fighting Words," Oregonian, 8 March 1992, B, 7, 10.

3 "War in Europe," Economist, 6 July 1991, p. 64.

${ }^{4} \mathrm{Ibid}$; Allan Bloom, The Closing of the American Mind, (New York: Simon and Schuster, Inc., 1987), PP. 19-43; Robert Hughes, Culture of Complaint: The Fraying of America, New York: Oxford University Press, 1993), PP. 3-151.

${ }^{5}$ Schlesinger, Disuniting of America, PP. 87-88; Steele, The Content of Our Character, PP. 1 175; Steele,"The opportunity society," Utne Reader, PP. 55-56; Cornell West, Race Matters, (Boston, Beacon Press, 1993), PP. 35-59.

6 "Mul ticulturalism...," Portland Observer, 6 May 1982,p. 1; Memorandum from Assistant Superintendents Fenwick and Schneider to Chief Consultant Asa Hilliard, 3 June 1982, PP. 2-5, Portland Public Schools' Archives; Report of Visitation, Asa Hilliard, 8 January 1987, Portland Public Schools' Archives. Some of these insights were derived through converstions in the early1990 s with individuals intimately involved with these processes who requested that their anonymity be honored.

${ }^{7}$ Ibid. Please see pertinent areas in chapters two, three and four along with their related sources.

${ }^{8}$ Ibid.

${ }^{9}$ Ibid; Committee on Race and Education, Race and Equal Education, PP. 194-196, Portland Public Schools' Archives; "Fighting Words," Oregonian, 8 March 1992, B, PP. 7, 10. 


\section{REFERENCES}

PRIMARY SOURCES

$\underline{\text { Archives }}$

Portland Public Schools: Records Center, and the Multicultural/Multiethnic Education Office.

\section{$\underline{\text { Books, }} \underline{\text { Articles, }}$ and Newspapers}

Adams, Bonnie Sue, et al. "Changing 'The Way Things Are Done Around Here." Educational Leadership (December 1991/ January 1992): 37-42.

“A daring connection." Oregonian (3 December 1990): B 18.

Adler, Jerry, “African Dreams.” Newsweek (23 September 1991): 42-45.

“African teachings draw criticism." Oregonian (18 November 1990): D, 1, 7.

"Afrocentricity stirs debates in U.S. schools." Oregonian (14 August 1991): A, 3.

“Afrocentrists Wage War on Ancient Greeks." Wall Street Journal (7 April 1993): 6.

“Afro-Fascism On The Rise." Heterodoxy 2, 1 (September 1993): 1, 10-12.

"After making swift, major reforms, school chancellor is unemployed." Oregonian (18 April 1993): C, 3. 
“A return to segregationist history." Oregonian (18 November 1990): B, 1.

“A Struggle Against Eurocentrism." Wall Street Journal (24 May 1993): 18.

"An invitation you should not refuse." Oregonian (13 February 1992): B, 2.

Asante, Molefi Kete. "Putting Africa at the Center." Newsweek (23 September 1991): 46.

"Multiculturalism Without Hierarchy: An Afrocentric Reply to Diane Ravitch." Unpublished, Portland Public Schools (Fall 1990): 1-14.

Banks, James A. "Multicultural Education: For Freedom's Sake." Educational Leadership (December 1991/ January 1992): 32-36.

"Baseline Essays add to mistakes of past." Oregonian (16 October 1991): B, 14.

"Battling Bias." Oregonian (10 May 1994): B, 1.

Begley, Sharon et al. “African Dreams.” Newsweek (23 September 1991): 42-50.

“Be skeptical." Oregonian (28 July 1983): B, 6.

“Black children said 'isolated' despite busing." Oregonian (8 December 1977): B, 3.

"Black Demagogues and Pseudo-Scholars." New York Times (20 July 1992): 10.

"Black leaders OK terms to mediate Tubman dispute." Oregonian (28 A pril 1982): $\mathrm{B}, 1$.

"Black student defends busing as broadening." Oregonian (26 September 1978): B, 1.

“Black studies program still raising questions." Oregonian (24 April 1989): B, 1, 8 . 
"Black United Front embarks on talent search of sorts for 'Saturday School." Oregonian ( 8 November 1987): B, 4.

“Blacks overruled again: By school board." Oregonian (15 April 1982): B, 7.

"Blacks support march, split on boycott." Oregonian (13 April 1982): B, 1.

"Blanchard fired for 'retreating." Oregonian (29 June 1980): C, 1.

“Board abandons Jefferson plan.” Oregonian (10 January 1978): B, 11.

“Board adopts revised teacher evaluation plan." Oregonian (14 July 1985): D, 12.

“Board eyes legal action." Oregonian (18 April 1982): B, 1.

"Board fails to OK Tubman mediation." Oregonian (25 April 1982): B, 1.

“Board's new goals draw fire." Oregonian (25 September 1984): B, 4.

"Board Oks mediation on school." Oregonian (27 April 1982): 1.

“Board to seek injunction." Oregonian (19 April 1982): A, 1.

"Board weighs racial balance worth." Oregonian (24 January 1986): D, 10.

"Bogle, Cawthorne field pointed questions from audience." Oregonian (14 December 1984): $\mathrm{D}, 2$.

Boyd, Alex, and Lenix-Hooker, Catherine J. "Afrocentrism, Hype or history?" Library Journal 117 (1 November 1992): 46.

Bray, Hiawatha. "Evangelical Racism?" Christianity Today (23 November 1992): $42-44$. 
“Busing and budgeting: a minority report." Willamette Week (2 October 1978): 2.

"Busing blasted at heated meeting." Oregon Journal (12 September 1978): 4.

"Busing of students necessary." Oregon Joumal (22 September 1978): 14.

"Busing said no cure for white escape." Oregonian (15 December 1977): B, 2.

"Cawthorne named school board chief." Oregonian (14 July 1980): C, 1.

Chavez Linda, et al. Alternatives to Afrocentrism. New York: Manhattan Institute, 1991.

Chmelynski, Carol. "Schools see benefits of 'multicultural' curriculum." School Board News (23 October 1990): 8.

“Citizen coalition calls for school recall halt." Oregonian (11 July 1980): B, 2.

“Citizens hear school integration plan." Oregonian (22 September 1978): B, 3.

"Civic leaders begin move to recall 4 on school board." Oregonian (18 June 1980): $\mathrm{B}, 1$.

"Class is out as Oakland rewrites texts." Oregonian (20 September 1991): 4-5.

“Cleveland principal draws criticism." Oregonian (1 October 1990): B, 4.

"Coalition pinpoints 'flaws' in school desegregation program." Oregonian (10 September 1978): B, 3.

"Coalition says review school policy results." Oregonian (14 December 1977): B, 13. 
“Coalition seeks planning role.” Oregon Journal (13 rabruary 1978): 2.

"Coalition stresses equity in school busing." Oregonian (22 September 1978): B, 3.

“Coalition will study school desegregation." Oregonian (24 October 1978): B, 4.

"Commission on Black Affairs plans strategy for year." Oregonian (6 August 1990): B, 3 .

"Company markets new set of crayons to match skin color." Oregonian (8 November 1991): C, 3.

"Conference studies racism." Oregonian (6 October 1991): B, 7.

Coughlin, Ellen K. "In Multiculturalism Debate, Scholarly Book on Ancient Greece Plays Controversial Part." The Chronicle of Higher Education (31 July 1991): 6-8.

Crump, Lucien and Loretta Tate. "Afrocentric Schools: Fighting a racist legacy." U.S. News \& World Report (9 December 1991): 75-77.

"Curricula of Color." The Wall Street Journal (1 July 1991): 1, A2.

“Curriculum Seeks to Lift Blacks' Self-Image." The New York Times (8 March 1989): A, 1, 24.

Davidson, Nicholas. "Was Socrates A Plagiarist?" National Review (25 February 1991): 45-46.

"Desegregation coalition reports community forum findings." Portland Observer (6 April 1978): 4.

“Desegregation, 'numbers game,' topic for study." Oregonian (12 December): B, 1.

“Desegregation panel raps Portland schools.” Oregonian (23 August 1991): C, 5. 
“Desegregation plan meets aims, but doubts remain." Oregonian (21 April 1985): C, 2.

“Desegregation Problems Ignored In Portland, Coalition Says." The Skanner (27 July 1978): $4-5$.

“Desegregation setup ignores black heritage.” Oregonian (26 September 1978): B, 8.

"Dissenters fault board: Blanchard fired for 'retreating." Oregonian (29 June 1980): C, 1-2.

“District asks injunction against black protests." Oregonian (21 April 1982): B, 1.

Early, Gerald. “Their Malcolm, My Problem.” Harper's Magazine (December 1992): 62-69.

“Economics questioned: Desegregation meet draws few." Oregonian (24 October 1978): B, 4.

“Education segregated." Oregonian (29 November 1990): B, 14

“Education supplement." Oregonian (2 December 1990): B, 13.

"Election to determine school board composition." Oregonian (27 March 1985): C, 1.

“End school board disruptions." Oregonian (14 April 1982): B, 6.

“Essays an insult." Oregonian (5 December 1990): B, 15.

"Fighting Words." Oregonian (8 March 1992): B, 7, 10.

"500 march to protest Tubman site." Oregonian ( 18 April 1982): B, 1. 
Flores, Herlinda Garza. "Please Do Bother Them." Educational Leadership (December 1991/ January 1992): 58-59.

Forte, Lorraine, V. "Schools embrace multicultural trend." Catalyst Voices of Chicago School Reform 2, 4 (December 1990): 1-20.

“Fringes of Afro-centrism." The Washington Times (13 November 1990): G, 1, 45.

"Front's Saturday School to open late." Oregonian (1 November 1990): B, 7.

“"Futurist' points way for school." Oregonian (28 February 1987): B, 3.

Gates, Henry Louis. "Beware of the New Pharaohs." Newsweek (23 August 1991): 47.

“Gains of Black United Front win respect.” Oregonian (21 July 1983): B, 4.

Gray, Paul. “Whose America?” Time (8 July 1991): 13-21.

“Group hits school busing as "unfair." Oregon Journal (31 March 1978): 13.

“Group promotes multiultural education.” Oregonian (11 November 1985): C, 2.

"Hearing on integration gets 'cool' response." Oregonian (20 September 1978): B, 6.

Henry, William. "Pride and Prejudice." Time (28 February 1994): 21-34.

"Herndon deplores city's 'two school systems'-rich, poor." Oregonian (13 March 1987): E, 2.

"Herndon raps plan to shift school board meeting site." Oregonian (12 April 1982): $\mathrm{B}, 1$. 
Hilliard, Asa. "Do We Have the Will to Educate All Children." Educational Leadership (September 1991): 31-36.

. "Why We Must Pluralize the Curriculum." Educational Leadership (December 1991/ January 1992): 12-14.

“History explains anger at decision.” Oregonian (23 April 1982): C, 11-12.

“Hughes on multiculturalism: Handle with care." Oregonian (14 May 1993): B, 6.

Hughes, Robert. “The Fraying of America." Time (3 February 1992): 44-49.

Hull, Jon D. “Do Teachers Punish According to Race?" Time (4 April 1994): 3031 .

"Hypersensitivity, on its way across America, tromps on First Amendment." Oregonian (28 November 1993): B, 12.

“Immigrants inundate a changed nation." Oregonian (29 July 1993): B, 5.

"Integration hearing: 2-way bus plan reaction mixed." Oregonian (14 September 1978): B, 8.

“Integration plans questioned." Oregonian (6 October 1978): B, 3.

"Issues: Cawthorn cites politics in education.: The Community Press (11 January 1978): 6.

Jaroff, Leon. “Teaching Reverse Racism.” Time (4 April 1994): 74-75.

Landers, Robert, K. "Conflict Over Multicultural Education.” Congressional Quarterly's Editorial Research Reports 1, 44 (November 1990): 682699.

"Leaders of school recall snub mayor's appeal." Oregonian (1 August 1980): C, 2. 
Leo, John. "A fringe history of the world." U.S. News and World Report (12 November 1990): 25-26.

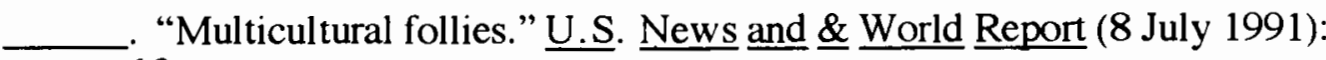
12.

“Let's study Tubman some more." Oregonian (28 April 1982): B, 6.

"Local schools approach with caution." The Washington Times (13 November 1990): $1,10$.

Magner, Denise K. "Controversial City College Professor Is a Study in Contradictions." The Chronicle of Higher Education (18 December 1991): A, 17-19.

"Mandatory 2-way busing urged to integrate Portland schools." Oregonian (10 September 1978): B, 8.

Marable, Manning, et al. "Black Voices: 8 views on the crisis in the AfricanAmerican community." Utne Reader (September/October 1991): 50-61.

“Marshall High takes over the world.” Oregonian (31 July 1990): B, 1.

"Martel, Erich. "A Multicultural Lesson: Don't replace Eurocentric myth with Afrocentric propaganda." Teacher Magazine (September 1991): 62-63.

“Measures for 'crisis' considered.” Oregonian (14 April 1982): B, 1.

Milner, David. “Are Multicultural Classroom Materials Effective?” Bulletin 12, 1 (January 1991): 9-10.

"Ministers want board to 'repent."' Oregonian (17 April 1982): B, 1.

Morrow, Lance. "The Provocative Professor." Time (26 August 1991): 19-20. 
Moses, Wilson J. "Eurocentrism, Afrocentrism, and William H. Ferris's The African Abroad, 1911." Journal of Education (173, 1 1991): 76-90.

Nash, Gary B. "The Great Multicultural Debate." Contention 1, 3 (1992): 128

"Multicultural curriculum in the PPS." Portland Observer (6 May 1982): 7-8.

"Multicultural training program stirs doubts." Oregonian (3 March 1986): C, 8.

"Multiethnic education aims for history's untold stories." The Washington Times (13 November 1990): 12.

"Neighborhoods fight upcoming budget cuts." The Community Press (27 September 1978): 2.

"New school chief seeks reconciliation." Oregonian (18 June 1980): B, 6.

"Parents hear coalition." The Community Press (27 September 1978): 8.

"Planning for changes on agenda for board." Oregonian (23 August 1983): B, 6.

"Portland is Pacemaker in black history studies." Oregonian (8 February 1989): A, 12.

"Portland School District's Baseline Essays Under Attack!" Portland Observer (28 November 1990): 4-5.

“Portland schools' curriculum criticized." Oregonian (26 June 1987): D, 3.

"Portland's schools divided into 2 systems, and one doesn't work." Oregonian, (24 April 1987): D, 13.

"Portland schools quietly moving to resegregation." Oregonian (14 April 1985): C, 2. 
"Portlanders air comments at final busing forum." Oregonian (6 October 1978): B, 12.

"Pro-blanchard faction recall target." Oregonian ( 24 June 1980): B, 1.

"Protesters disrupt meeting." Oregonian (30 March 1982): B, 1.

"Public schools reflect more ethnic diversity." Oregonian (13 September 1991): 16.

"Putting Africa on the Map, 'racist' history assailed." The Washington Times (13 November 1990): 1, 10-11.

Ravitch, Diane. "Multiculturalism, E Pluribus Plures." The American Scholar (Summer 1990): 337-355.

. "A Culture in Common." Educational Leadership (December 1991/ January 1992): 8-11.

_ "Learning by Race." Wilson Quarterly (Autumn 1990): 16.

"Recall launched toward 3." Oregonian (23 July 1980): B, 1.

“Response mixed on busing plan." Oregon Journal (28 September 1978): 5.

"Revisionist history." Oregonian (29 November 1990): B, 14

Schmidt, Peter. "Educators Forsee 'Renaissance' in African Studies." Education Week (18 October 1989): 8.

“School Board drops Newman Plan." Portland Observer (12 January 1978): 5.

"School board efforts, Mayor urges end to recalls." Oregonian (31 July 1980): C, 1. 
"School board fails to write parent policy." Oregonian (28 August 1980): B, 1.

"School board race recalls '79 impasse." Oregonian (22 March 1981): F,1,3.

“School Board shifts Blanchard's aides." Oregonian (24 June 1980): 1.

"School board shuns full public debate." Oregonian (23 November 1983): B, 5.

"School board told to return to court." Oregonian (20 February 1985): B, 2.

"School closure, pairing ruled out." Oregon Journal (29 September 1978): 6.

“School finance split." Oregonian (8 December 1977): B, 3.

"School imbalance: Blacks dominate enrollment." Oregonian (8 February 1978): B, 4.

"School patterns shift in five years under Portland desegregation plan." Oregonian (14 April 1985): C, 5.

"Schools ask views on integration." Oregon Journal (11 September 1978): 2.

"Schools must respond to multicultural world." Oregonian (25 November 1990): B, 12-13.

"Schools to change plan for parent involvement." Oregonian (19 August 1980): B, 1 .

"Shouts pierce busing meet." Oregon Journal (26 September 1978): 3

“600 boycott classes in protest at Jackson.” Oregonian (21 April 1982): B, 1.

Smoler, Fredric. "What Should We Teach Our Children About American History?" American Heritage (February/March 1992): 45-52. 
"Social Indoctrination gets in way of necessary school reform." Oregonian (9 May 1993): C, 10.

"Staff training at PPS." Portland Observer (13 May 1982): 12.

Steele, Shelby. "The Opportunity Society." Utne Reader (September/October 1991): 55-56.

Steinberger, Elizabeth. "America's identity in transition." The $\underline{\text { School }}$ Administrator (April 1991): 9-22

"Strategy addresses protestors." Oregonian (11 April 1982): B, 1.

“Suspicion on Racism Rift.” New York Newsday (19 August 1991): 3, 25-29.

"Swap Americanism for multiculturalism." Oregonian (22 May 1994): B, 8.

"Teachers divided on new Afrocentrism." The Washington Times (13 November 1990): 24.

"Teaching 'diversity' is code for politicizing campuses." Oregonian (1 July 1993): C, 9 .

“Temporarily fogged or fatally tinted?" Oregonian (27 November 1990): B, 3.

“The Essays! More Attacks and Support." Portland Observer (12 December 1990): $1-2$.

“The Greatest Danger We Face.” Washington Post (25 July 1993): P, 4-6.

“Top 10 problems with baseline essays." Oregonian (16 April 1994): B, 7.

“Tubman decision best, least costly." Oregonian (23 April 1982): C, 11. 
“ $\$ 20,000$ budget eyed in school recal effort." Oregonian (20 June 1980): B, 1.

Viadero, Debra. "Afro-Centric Study Boosts Performance By Black Students, Researcher Finds." Education Week (14 November 1990): 6.

_ . "Battle Over Multicultural Education Rises in Intensity." Education Week (28 November 1990): 1, 11-13.

"War in Europe." Economist (6 July 1991): 64.

"When Blacks Were First Bused to Ainsworth School." Oregonian (19 February 1978): B, 6.

“Where we stand: Don't Sacrafice Accuracy for Diversity, Making a Multicultural Curriculum" New York Times (10 November 1991): 4.

"Where we stand: Multicultural and Global Education: Value Free?" New York Times (6 January 1991): 49.

"Where we stand: Unity, Not Disunity, Is the Real Story." New York Times (12 August 1990): 32.

"Wilson forum on busing draws diverse opinions." Oregonian (28 September 1978): $\mathrm{B}, 3$.

“Workshop focuses on cultures." Oregonian (15 February 1986): C, 4.

Wortham, Anne. "Afrocentrism Isn't the Answer for Black Students in American Society." Education Digest (November 1992): 62-66.

Wright, Willie J. "The Endangered Black Male Child." Educational Leadership (December 1991/ January 1992): 14-16.

"Yes, Portland's black community is an entity." Oregonian (6 October 1978): 3. 
Oral Interviews

Anonymous, telephone and personal interviews with author, 1993-1996. 


\section{SECONDARY SOURCES}

\section{Books and $\underline{\text { Articles }}$}

Aptheker, Herbert. The Colonial Era: A History of the American People. New York: International Publishers, 1966.

Asante, Molefi Kete. Afrocentricity. Trenton, N.J.: Africa World Press, 1992.

Bennett, David H. The Party of Fear: From Nativist Movements to the New Right in American History. Chapel Hill, N.C.: University of North Carolina Press, 1988.

Berman, Paul, ed. Blacks and Jews: Alliances and Arguments. New York: Dell Publishing, 1994

Bloom, Allan. The Closing of the American Mind. New York: Simon and Schuster, Inc. 1987.

Blumberg, Rhoda Lois. Civil Rights: The 1960s Freedom Struggle. Boston, Mass.: Twayne Publishers, 1991.

Boesche, Roger, ed. Selected letters on Politics and Society. Berkeley, Ca.: University of California Press, 1985.

Buell, Emmett $H$. School Desegregation and Defended Neighorhoods. Lexingon, Mass.: Lexingon Books, 1982.

Bureau of the Census. Historical Statistics of the United States, Colonial Times to 1970. Washington, D.C.: U.S. Department of Commerce, 1976.

Carmichael, Stokely, and Hamilton, Charles V. Black Power: The Politics of Liberation in America. New York: Alfred A.Knopf, Inc., 1966. 
Cleaver, Eldridge. Soul on Ice. New York: McGraw-Hill, 1968.

Colburn, David R., and Pozzetta, George E. eds. America and the New Ethnicity. Port Washington, New York: Kennikat Press, 1979.

Corner, Trevor, ed. Education in Multicultural Societies. New York: St. Martin's Press, 1984.

Craft, Maurice, ed. Education and Cultural Pluralism. Philadelphia, Penn.: Falmer Press, 1984.

De Crevecoeur, Hector St. John. Letters From An American Farmer. New York: E.P. Dutton and Co. Inc., 1912.

Didion, Joan. The White Album. New York: Simon and Schuster, 1979.

Dinnerstein, Leonard, and Reimers, David M. Ethnic Americans. New York: Harper and Row, Publishers, Inc., 1982.

Natives and Strangers: Ethnic Groups and the Building of America. New York: Oxford University Press, 1979.

Eagles, Charles W., ed. The Civil Rights Movement in America: Essays by David Levering Lewis etal. Jackson, Miss.: University Press of Mississippi, 1986.

Ellison, Ralph. Shadow and Act. New York: Vintage Books, 1953.

Invisible Man. New York: Random House, 1952.

Fitzpatrick, J.C., ed. George Washington's Writings. Washington, D.C.: U.S. Govt. Print. Off., 1938.

Foner, Philip S.,ed. Life and Writings of Frederick Douglass. New York: International Publishers, 1950. 
Griffith, Cyril E. The African Dream: Martin R. Delany and the Emergence of PanAfrican Thought. Universtity Park, Penn.: University of Pennsylvania State University, 1975.

Hill, Herbert, and Jones, James E., Jr., eds. Race in America: The Struggle for Equality. Madison, Wis.: University of Wisconsin Press, 1993.

Holmes, L.G., ed. The Real Estate Handbook. New Jersey: Prentice-Hall, Inc., 1948 .

Horowitz, David A. Beyond Left and Right. Chicago, Ill.: University of Illinois Press, 1997.

Horowitz, David A., Carroll, Peter N. and Lee, David D. On The Edge: A History of America Since World War II. St. Paul, Minn.: West Publishing company, 1989.

Hughes, Robert. Culture of Complaint: The Fraying of America. New York: Oxford University Press, 1993.

Jacques-Garvey, Amy., ed. Philosophy and Opinions of Marcus Garvey. New York: Atheneum, 1969.

Jensen, Joan M. The Price of Vigilance. Chicago, Ill.: Rand McNally, 1968.

Jordan, Winthrop D. White Over Black: American Attiturdes Toward The Negro, 1510-1812. Chapel Hill, N.C.: University of North Carrolina Press, 1968.

Karenga, Maulana (Ron). Introduction to Black Studies. Los Angeles, Ca.: University of Sankore Press, 1993.

Killens, John Oliver. Black Man's Burden. New York: Trident Press, 1965.

Kimball, Roger. Tenured Radicals: How Politics Has Corrupted Our Higher Education. New York: Harper and Row, Publishers, 1990. 
“Limited desegregation backed." Oregonian (14 October 1978): B, 4.

Maizlish, Robert and Stephen E, eds. New Perspectives on Race and Slavery in America: Essays in Honor of Kenneth $\underline{\mathrm{M}}$. Stampp. Lexington, Ky.: University Press of Kentucky, 1986.

McLemore, Dale S. Racial and Ethnic Relations in America. Boston, Mass.: Allyn and Bacon, 1980.

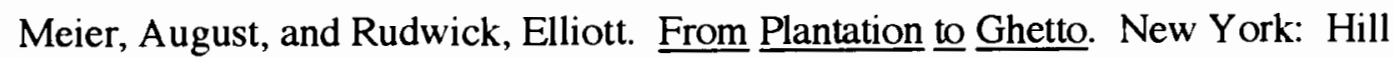
and Wang, 1966.

Millner, Darrell. The Urban League of Portland, On the Road to Equality: 50 years. Portland, Or.: Urban League, 1995.

Myrdal, Gunnar. An American Dilemma. New York: Harper and Row Publishers, Incorporated, 1944.

Nash, Gary B. Red, White and Black. Englewood Cliffs, New Jersey: PrenticeHall, Incorporated, 1974.

Novak, Michael. The Rise of the Unmeltable Ethnics: Politics and Culture in the Seventies. New York: Macmillan, 1972.

Novick, Peter. That Noble Dream: The "Objectivity Question" and the American Historical Profession. New York: Cambridge University Press, 1988.

Patterson, Orlando. "Rethinking Black History." Harvard Educational Review 41, 3 (August 1971): 297-315.

Porte, Joel, ed. Emerson in his Joumals. Cambridge, Mass.: Belknap Press of Harvard University Press, 1982.

Pozzetta, George E., ed. American Immigration and Ethnictiy: Nativism, Discrimination, and Images of Immigrants. New York: Garland Publishing, Inc., 1991. 
Pride, Richard A. The Burden of Busing: The Politics of Desegregation in Nashville, Tennessee. Knoxville, Tenn.: University of Tennessee Press, 1985.

Rist, Ray C. The Invisible Children: School Integration in American Society. Cambridge, Mass.: Harvard University Press, 1978.

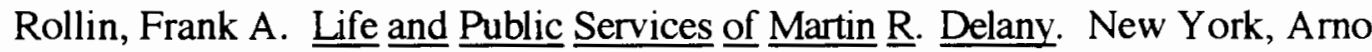
Press, 1969.

Saalfeld, Lawrence J. Forces of Prejucice in Oregon, 1920-1925. Portland, Or., Archdiocesan Historical Commission, 1984.

Schlesinger, Arthur, Jr. The Disuniting of America: Reflections on a Multicultural Society. New York: W.W. Norton and Company, 1991.

Solomon, Barbara Miller. Ancestors and Immigrants: A Changing New England Tradition. Cambridg, Mass.: Harvard University Press, 1956.

Steele, Shelby. The Content of Our Character. New York: St. Martin's Press, 1990.

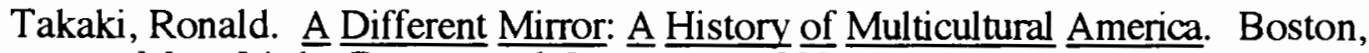
Ma.: Little, Brown, and Company, 1993.

Wagstaff, Thomas. Black Power: The Radical Response to White America. Beverly Hills, Ca.: Glencoe Press, 1969

Weatherford, Willis D. Race Relations: Adjustment of Whites and Negroes in the United States. New York: Negro Universities Press, 1969.

West, Cornell. Race Matters. Boston, Mass.: Beacon Press, 1993.

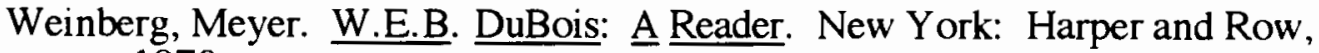
1970. 
Woodward, C. Vann. The Strange Career of Jim Crow. New York: Oxford University Press, 1974.

X, Malcolm. The Autobiography of Malcolm X. New York: Grove Press, 1965. 


\section{APPENDIX A \\ CHRONOLOGY OFMAJOR EVENTS: DESEGREGATION/INTEGRATION 1960-82 at PORTLAND PUBLIC SCHOOLS}

Presented below, is a chronology of significant District responses aimed at the elimination of racial isolation and for assuring equal education al opportunity in School District \#1:

1962 NAACP and public involvement as Board of Education conf ronts racial isolation problems.

1963 Committee on Racial Inbalance protests de facto segregation. Board of Education appoints Committee on Race and Education, chaired by Judge Herbert Schwab. The Committee was charged with the responsibility to stucy the problems of racial isolation and to make recommendations for resolutions.

1964 Committee on Race and Education report to the Board of Education. Beginning of the Administrative Transfer Program.

1965 Established Model Schools-Compensatory Education Program. 
1966 Began extensive staff in-service training in support of inter-group and interracial understanding.

1967 Started the suburban transfer program.

1968 Staff report to the Board of Education of desegregation alternatives; Eliot is established as an Early Childhood Center.

1969 New superintendent hired, Robert Blanchard. Superintendent's recommendation on reorganization. Boundary changes. Opening of Adams high School.

1970 Board of Education adopts Superintendent's reorganization plan, Portland Schools for the Seventies. The plan called for: 1. Decentralization of the district into three administrative areas; 2 . Advisory committees established in each area; 3 . Middle schools; 4 . Early Childhood Centers to be established in inner city core areas.

1971 School bond issue fails, Board of Education review of alternatives following failure of levy. Superintendent's plan on social-economic balance; Board rejected the plan in the absence of a court order. Decisions made at this time were: 1. Closure of Holladay School; 2. Establish Early childhood Center at Irvington; 3. Boundary changes affecting Jefferson, Roosevelt, Grant; 4. Accelerate the Administrative Transfer program. 
1972 Recruitment of 500 new students to the Administrative Transfer program (total at 725). Accelerated in-service training program in support of desegregation.

1973 Development of State Board Policy on racial imbalance implementation guidelines. Portland Board of Education affirmative action adoption. Conversion of Humboldt to an Early Childhood Center. Title VII Emergency School Aid Act project begins.

1974 State Board adoption of policy on racial imbalance implementation guidelines. Title IVA Indian Education Act begins.

1975 Conversion of Sabin to an Early Childhood Center. Establishment of Columbia/Whitaker and Sellwood Middle Schools. Board of Education adopts the McPherson Memorial Award Program for Interracial Understanding.

1976 Beginning of conversion of Woodlawn and Vernon to Early childhood Centers. Beginning of fundamental school at Boise. Teacher transfers for racial balance accomplished.

1977 Fernwood, Hosford, Kellogg become middle schools. Glenhaven becomes an intermediate school. Jefferson boundary change proposal. Formation of the community coalition for School Integration. Disciplinary procedures revised. Vernon becomes Early childhood Center. 
1978 Report of the Community Coalition for School Integration. Middle schools approved at Beaumont and Ockley Green. Bilingual education program expanded.

1979 The Board responds to community concerns and adopts long and short range resolutions, which become the basis of the new Comprehensive Desegregation Plan. Eliot becomes Early Childhood Center.

1980 Comprehensive Desegregation Plan, Phase I, implementation begins.

1981 Development of comprehensive Desegregation Plan, Phase II. Tubman Middle School opens. Space added at Humboldt and Eliot.

1982 Comprehensive Desegregation Plan, Phase II, implementation begins. 


\section{APPENDIX B}

In December of 1991, Educational Leadership published "On the Portland Plan: A Conversation with Matthew Prophet," in which he explained his experiences related to and perspective on Portland Public School's Afrocentric curriculum. Prophet, who had been a superintendent in Lansing, Michigan, was working to find a way to incorporate more teaching about black history, achievement, and culture in classrooms there. Prophet indicated that he never saw that project bear fruit, but accepted the Portland job in 1982 already convinced that black children needed to know more about their heritage. "My basic reason is based more on my own individual experiences than on any eloquent philosophical rationale," explained Prophet. Growing up as a black in Mississippi during the 1930s, and having attended a school with all black students and teachers, "where you couldn't go beyond 8th grade with public tax support," pervaded his memory and perspective. Up until he was 48 years old, he reflected, "my life was devoid of having been given the opportunity to learn about the important and significant contributions by my ancestors." Prophet then submitted to a long list of questions centering on the African-American Baseline Essays:

What made the creation of these essays necessary? We felt that there was a gap in the knowledge of our students and staff about ethnic groups besides Europeans. We needed to establish a set of baseline information that shows the contributions of various geo-cultural groups in each of the major disciplines: social studies, science, mathematics, language arts, and art and music.

Are there basic philosophical ideas you're trying to get across through the baseline data? We have a number of recurring themes that we wanted everyone to 
buy into as much as possible; they really undergird practically everything we're attempting to do. The first of those themes is that we believe that early civilization evolved in Africa, and that Africa is the cradle of civilization. Egypt was and still is a significant African civilization. People of African descent have a history that precedes slavery and civil rights. The culture of African people was not destroyed by slavery.

Another overriding principle is that each of the six geo-cultural groups has made significant contributions. No geo-cultural group is innately inferior or superior to another. People, wherever they are, are interdependent and need one another. We're attempting to build in all of our kids, whatever their ethnicity or cultural identity, an awareness of their culture and ethnic heritage. We're trying to have them develop an understanding and respect and appreciation for the history, culture. and contributions of all groups of people, trying to eliminate personal and national ethnocentrism so that one understands that a specific culture is neither intrinsically inferior or superior to another. We're trying also to give some general suggestions that we think teachers should integrate into what they do that will bring about greater understanding and appreciation of cultural diversity.

Some critics say the essays in fact work against an appreciation of cultural diversity: that they actually take on a tone of superiority on behalf of AfricanAmericans. Well, that could be. We had to begin somewhere, and we don't put our professional reputations on any of these essays to the extent of saying that all of their content is necessarily 100 percent accurate.

This is the first edition, and we're constantly receiving suggestions on ways that their content can be improved ... I did my very best, with the input and expertise 
from within Portland and around the country, to synthesize these views in a way that would minimize conflict and yet not refute what was most documentable as events that had actually occurred.

With each reprinting of the baseline essays, we've corrected known errors. ... There are some who, by virtue of their having gone through the traditional American educational system, have ingrained in their minds certain historical "truths" that are irrefutable to them.

If historians and scholars can't agree on some of these points, how does a teacher make sense of all the conflicting information? Teachers ... need to be exposed to new information, and perspectives ... Students need to know the history of African peoples in antiquity and the current contributions of Americans of African descent: we don't have to organize this treatment around slavery and civil rights ... We think that the content of the essays themselves is of less importance than the overriding principle of respecting all geo-cultural groups. It's good to argue about content ... The purpose[however] is to gain recognition that all people have made contributions.

Doesn't the publishing of the essays constitute a major endorsement, just as if you'd endorsed a particular textbook that teachers could use? Your support for the factual accuracy of the essays seems to be lukewarm. The essays contain information that is the best that we can determine at this time, based upon input from a variety of experts in the particular disciplines involved. We don't have to necessarily agree what truth is. If we raise the level of awareness enough that certain issues become arguable, that represents a significant advance over where we are 
now, which-at least in my lifetime -has been a singularistic, Eurocentric perspective. There has to be, simply, a greater appreciation for all people.

Some would say there's a conflict within the multicultural education movement between advocates of a pluralistic approach, in which the roles of many cultures are treated, and those who promote a more separatist approach, which teaches children through the lens of their own culture. The second approach has been identified more with the Afrocentrist view. Does Portland follow the approach of those who say: "Look, we've got 95 percent African-American kids in this school; we've got to teach them the curriculum through the lens of AfricanAmericans?" No, we don't see it that way. We see the contributions of Africans as having a distinct nature, a distinct character, a distinct, provable historical context. We also see, similarly, the potential contributions that have been made by all ethnic groups. We had to begin somewhere. We began with the African-American history and culture and an attempt to share that geo-cultural group's world view. The Eurocentric view of Africans is already well entrenched in both the curriculum and in our society ...

It's impossible to view phenomena without an implicit view. That view is usually Eurocentric, and we are simply acknowledging that there are other points of view. But we are not presenting any particular ethnic or cultural group as being inherently superior to another. We're trying to build a comprehensive mosaic to show all people have mad contributions.

What about those who say that the contributions of the West have to be at the forefront of our core curriculum, because it's where we derived our government and many of our traditions? Well, I think world studies needs to be at the foref ront ... 
Many of the deficiencies that we're now experiencing as Americans stem from our rather insular view of ourselves and our Western orientation, without a clear understanding of logic and principles of reasoning and strategies and understandings that others around the globe have.

But hasn't a lot of progress been made? History textbooks are far less distorted than in the past, and teachers are generally much more sensitive to the cultural differences among students. I know in certain areas, particularly the social studies, there's been some success in infusing multicultural principles ...[A\} lot more progress needs to be made in certain areas of the sciences and in math.

It's really a travesty that a single school system had to generate the so-called textbook of baseline essays. But, our having done that, we have stimulated across this country a discussion-a movement is under way. I predict that the textbook industry, by virtue of the pressure that's going to be exerted nationwide and the arguments that are ensuing now, will certainly begin to change.

How successful would you say Portland has been in infusing the material in the baseline essays into school curriculums? The first phase of our plan is the AfroAmerican baseline essays. Those have been implemented. I can't claim that they've been implemented to a 100 percent success level. There are varying levels of acceptance. We've had more success at the elementary level than at the middle school level, more success at the middle school level than at the high school level.

Why is that? We've been very specific in terms of the development of our $\mathrm{K}$ 5 lesson plans for the African-American content. And teachers are more used to integrating information because they have students for more than one subject. It's more difficult for us to infuse this content in the high school, which is more 
discipline-based. We're developing now a particular curriculum matrix that can also be integrated into the holistic learning objectives at the high school. ...We still have a long way to go.

You seem to have a deep personal interest in multicultural education. How did that come about? Growing up, I went to segregated schools in Mississippi-what amounted to educational apartheid. And I've been powerfully influenced by spending 20 years in military service in Korea, in Vietnam, and in Europe, where I came in contact with many cultures and ethnic groups around the world. My interest not only in promoting cultural understanding but also in conflict resolution evolved from these experiences-serving as a nuclear weapons officer, finding out the futility of war ...

So in Portland, we're not only interested in helping students learn about other cultures, we'd like to promote conflict resolution.

Why are conflict resolution and multicultural education linked? Well, in America we still have, unfortunately, a lot of hatred and a lot of racism. Out of this hatred and racism comes conflict in all segments of our society. I believe that for future generations of Americans to benefit from the efforts that we're making, they need to understand that many of these conflicts are based on these ideas of intrinsic inferiority and superiority. We're trying to eliminate that attitude, and we believe that linking multicultural education and conflict resolution will help. 